\title{
Regulation and Civil Liability Under the California Corporate Securities Act: III
}

\author{
T.W. Dahlquist*
}

\begin{abstract}
This is the third of a series of articles being published under the above title.
\end{abstract}

\section{CIVIL LIABILITY UNDER THE PERMIT PROVISIONS OF THE ACT}

\section{General.}

While the permit provisions of the Act are replete with sanctions and penalties, they are wholly silent as to civil liability for violations of the Act. The Act does not prescribe any remedies or define any measure of damages nor does it purport to specify the persons who are civilly liable nor the persons who may enforce liability. It does not even prescribe any period for limitation of civil actions. All of these questions must be resolved by judicial interpretation of the express sanctions and penalties contained in the Act.

In such a situation, as has been stated in a leading case, ${ }^{1}$ construing the securities act of a sister state, the Act "must be interpreted or construed so as to effectuate the purpose of the Legislature ascertamed from the several parts of the statute and the meaning fairly attributable to all its words, considered in connection with the question leading to its enactment, the subject to which it is applicable, the pre-existing state of the common and statutory law, the mischief to be remedied, and the main object to be accomplished, to the end that it will be given an effect in harmony with common sense and sound reasoning."

The rule in California, ${ }^{2}$ which is in accord with the great weight of authority, ${ }^{3}$ is that the Act must be given a liberal construction.

Express Sanctions and Penalties in the Act.

The Act itself expressly provides the following separate sanctions for violation of the permit provisions of the Act: power of the Com-

*A.B., J.D., University of California; member of the California Bar.

1 Kneeland v. Emerton (1932) 28 Mass. 371, 183 N.E. 155.

2Agnew v. Daugherty (1922) 189 Cal. 446, 209 Pac. 34; People v. McCalla (1923) 63 Cal. App. 783, 220 Pac. 436; People v. White (1932) 124 Cal. App. 548, 12 P. (2d) 1078; People v. Jackson (1937) 24 Cal. App. (2d) 182, 74 P. (2d) 1085.

3 (1937) 23 Iowa L. REv. 102. 
missioner (a) to suspend or revoke any permit (section 4); (b) to order an issuer to desist and refrain from further sales of its securities (section 5); and (c) to enjoin violations or threatened violations of the Act or permit (section 19). It also expressly makes void any security issued without a permit (section 16). In addition, it provides criminal penalties for violations of the permit provisions of the Act including failure to obtain a permit or to comply with any permit (sections 17 and 18).*

The greatest preventive of fraud and exploitation under the Act is, of course, the extremely broad admimistrative power of the Commissioner, at the inception of a new issue, either to deny a permit or to grant it subject to conditions. It is also to be observed that the first three sanctions mentioned above are merely prophylactic in nature and are designed solely to prevent future sales of securities. None of them sheds any light on the question of civil liability for completed violations. As a consequence, the entire structure of civil liability for violations must be based on the construction of (a) the voiding section, and (b) the criminal penalties.

\section{The Voiding Section and the Criminal Penalties.}

The greatest confusion in the cases has resulted from misinterpretations and misapplications of the so-called "voiding" section (section 16) and the failure clearly to differentiate the effects of that section from the effects of the criminal penalties.

Many of the decisions, without either citing or quoting the voiding section of the Act, contain loose and general statements to the effect that any security sold or issued without a permit or in violation of the terms of a permit is void. One case even goes so far as to state that any security sold in violation of any provision of the Act is void ${ }^{5}$ - a palpable misquotation of the Act and language that is wholly unnecessary for the result reached in that case.

4 The sanctions and penalties for violations of the dealer regulation provisions of the Act are noticeably different since no provision makes void any security sold in violation of the dealer regulation provisions of the Act. Such provisions, hovever, do contain sanctions substantially similar to the first three above mentioned. ( $C f$. respectively, section 7, suspension or revocation of broker's certificate; section 13, stop-order power as to sales by brokers-first added in 1925 in old section 9 ; and section 19, injunction power which applies to brokers as well as to issuers.) The criminal penalties in sections 17 and 18 apply to violations of the dealer regulation provisions as well as to violations of the permit provisions of the Act.

5 Castle v. Acme Ice Cream Co. (1929) 101 Cal. App. 94, 281 Pac. 396, kearing den., (Dec. 2, 1929). 
The legislative history of the voiding section is relatively simple. At all times until the amendment of 1931 the voiding section of the Act read as follows:

"Section 12: Every security issued by any company, without a permit of the commissioner authorizing the same then in effect, shall be void, and every security issued by any company, with the authorization of the commissioner but not conforming in its provisions to the provisions, if any, which it is required by the permit of the commissioner to contain, shall be void."

In 1931 , old section 12 was replaced by a new section $16,{ }^{6}$ which remained in effect only for two years. In 1933, section 16 was amended to read as follows (and as so amended has continuously remained in effect):

"Section 16: Every security issued by any company without a permit of the commissioner authorizing the same then in effect, shall be void, and every security issued by a company with the authorization of the commissioner but which has been sold or issued in nonconformity with the provisions, if any, contained in the permit authorizing the issuance or sale of such security, shall be void."

Until 1931 the criminal provisions were contained in sections 13 and 14 of the Act, which laid penalties on persons causing the "sale" or "issue" of securities contrary to the provisions of the Act, or in nonconformity with the permit. Section 13 declared that:

6 "Section 16: Every security issued by any company, without a permit of the commissioner authorizing the same then in effect, and every security issued by any company, with the authorization of the commissioner but not in substantial conformity with such authorization, and all contracts, whether executed or executory, for the purchase thereof, shall be voidable at the election of the holder thereof, or purchaser thereunder unless within sixty days after written notice of such irregularity in the issuance of such security has heen given to the commissioner, he shall issue a permit authorizing the issuance of all securities of the same issue then issued, outstanding and/or subscrihed as of the date and in the manner of their actual issuance, and the commissioner is authorized, in his discretion, to issue such subsequent permit. If said permit is issued within said time none of said securities shall be voidable by reason of being issued without a permit or by reason of heing issued otherwise than in conformity with the terms of the original permit."

The effect of the 1931 amendment has given rise to considerable discussion. See $6 \mathrm{~A}$ Cal. Jur. 559; Baitantine, Catifornia Corporatton Laws (2d ed. 1938) 379 et seq. However, the supreme court has not passed on the effect of this amendment. Even though securities issued without a permit or in violation of the terms of a permit during this period were not void, it would appear clear that any contracts or other transactions entered into in violation of the Act are illegal under the rule applied in the leading case of Smith v. Bach (1920) 183 Cal. 259, 191 Pac. 14, hereinafter discussed, and by reason of the provisions of Civil Code sections 1598 and 1599. It was so held by the district court of appeal in the case of Wread v. Coffey-Murray, Inc. (1941) 42 Cal. App. (2d) 783, 110 P. (2d) 123. 
"Every company which shall directly or indirectly offer for sale, or negotiate for the sale of or sell, or issue, or cause to be issued any security contrary to the provisions of this act ... shall be guilty of a public offense and shall be punishable by a fine not exceeding ten thousand dollars."

Section 14 provided that "every officer, agent, or employee of any company, and every other person who knowingly ... aids in the issue or sale of . . . any security, in nonconformity with a permit ... or contrary to the provisions of this act . . . is guilty of a public offense...."

Present sections 17 and 18 are substantially similar to old sections 13 and 14, respectively. Neither section 17 , section 18 nor any other provision of the Act, except only section 16, expressly declares that securities should be void by reason of a violation of the Act.

The juxtaposition of section 16 with sections 17 and 18 and the essentially different language used in the different sections clearly show that the legislature intended a different consequence to arise from a violation under sections 17 and 18 from that resulting from a violation under section $16 .^{\top}$ Furthermore, under the doctrine of expressio unius est exclusio alterius, since the legislature in section 16 has expressly attached specific consequences, namely, that the security shall be void, to noncompliance with certain provisions of the statute but not to others, it will be presumed that such consequences are not intended to apply to noncompliance with such other provisions. ${ }^{8}$

Sections 17 and 18 merely declare certain acts to be public offenses and do not expressly pronounce such acts to be void or illegal in a civil sense.

While some other jurisdictions hold that the penalty, expressly provided for a violation in comparable statutes, is exclusive and does not make contracts either void or voidable, ${ }^{9}$ the rule in California is to the contrary.

7 "... When essentially different language is used in the same connection in different parts of a statute it will be presumed that a different meaning and effect were intended." 23 CaL. Jur. 754 ; see also, McCarthy v. Board of Fire Comm'rs (1918) 37 Cal. App. 495, 174 Pac. 402.

8 Perkins v. Thornburgh (1858) 10 Cal. 190, 192. See also, Black, INTERPrETATion of Laws (2d ed. 1911) $\$ 72$.

9 E.g., Sajor v. Ampol, Inc. (1937) 275 N. Y. 125,9 N. E. (2d) 303 , opinion by Justice Cardozo, holding that a contract made by a dealer who had not complied with the Martin Act was nevertheless valid and enforceable and that the express penalties provided in the Act are exclusive. 
In the leading, often-cited case of Smith v. Bach it was. held:

“... That, where a statute prohibits or attaches a penalty to the doing of an act, the act is void, and this, notwithstanding that the statute does not expressly pronounce it so, and it is immaterial whether the thing forbidden is malum in se or merely malum prohibitum. A statute of this character, prohibiting the making of contracts except in a certain manner, ipso facto makes them void if made in any other way. 13 Cyc. $351 ; 13$ Corpus Juris p. 410 . The imposition by statute of a penalty implies a prohibition of the act to which the penalty is attached, and a contract founded upon such act is void. This general rule finds support in the decisions of this state."10

The general rule, under California authorities, is that where a statute is enacted for the protection of the public, and makes acting without a license illegal by imposing criminal punishment, the penalty implies a prohibition so that a contract founded on acts by an unlicensed person is void and unenforceable, though not expressly so declared by the statute. The rule has been applied in innumerable cases arising under the Act. ${ }^{11}$

Other cases rest the illegality of any contract made in violation of the Act on Civil Code sections 1598 and 1499, which in effect provide that a contract having an unlawful object is void.

It would appear clear that the incidences of civil liability are radically different in the case where the security itself is void (or, as some of the cases phrase it, "a mere blank piece of paper"12) in contrast to the case in which only the transaction is illegal, but the security itself is not void. The differences, it is submitted, go to questions of the nature of the remedy, persons entitled to recover, and, possibly, limitations of action. ${ }^{13}$

10 (1920) 183 Cal. 259, 191 Pac. 14, citing Berka v. Woodward (1899) 125 Cal. 127, 57 Pac. 777, 45 L. R. A. 420, 73 Am. St. Rep. 31, and cases there cited, and Bentley v. Hurlburt (1908) 153 Cal. 796, 96 Pac. 800.

11 Otten v. Riesener Chocolate Co. (1927) 82 Cal. App. 83, 254 Pac. 942 (holding a contract for the purchase of stock void although the stock itself was not void); Live Oak Cemetery Ass'n v. Adamson (1930) 106 Cal. App. 783, 288 Pac. 29; Duntley v. Kagarise (1935) 10 Cal. App. (2d) 394, 52 P. (2d) 560 (holding transaction illegal although stock not void).

12 Black v. Solano Co. (1931) 114 Cal. App. 170, 299 Pac. 843; Cecil B. De Mille Productions v. Woolery (C. C. A. 9th, 1932) 61 F. (2d) 45 ; Boss v. Silent Drama Syndicate (1927) 82 Cal. App. 109, 255 Pac. 225 (security wholly nonexistent); Klinker v. Guarantee Title Co. (1929) $98 \mathrm{Cal}$. App. 469, 277 Pac. 177 (stock void, spurious and worthless-the void certificates of stock are not even choses in action).

13 These differences particularly apply with respect to violations of the dealer regulation provisions of the Act which are directed not against the issue of securities but to the resale, contrary to the provisions of the Act, of securities already validly issued. 
Section 12, as it existed prior to the 1931 amendment, was peculiarly worded and because of its ambiguity there was a great deal of confusion in the earlier decisions as to whether a security issued in violation of the terms of a permit was void to the same extent as one issued without a permit. ${ }^{14}$

Up to January, 1930, no California appellate court had expressly ruled that securities issued in contravention of the conditions of the permit are void, although the sale of such securities was clearly illegal..$^{15}$ A careful examination of the early decisions discloses that the courts held securities void only in cases where there was a complete lack of permit, and in cases of violation of the conditions of the permit they were careful to confine their decisions to the illegality of the sale or transaction only. However, in later cases, securities issued in violation of the terms of a permit have been held void under section 12. The first case which was squarely in point was Live Oak Cemetery Ass' $n$ v. Adamson, ${ }^{16}$ decided in January of 1930, in which the court in effect held that stock which was issued in noncompliance with the terms of the permit is tantamount to stock issued without a permit. The same rule was announced by the supreme court in Kahle v. Stephens ${ }^{15}$ and Regan v. Albin. ${ }^{18}$ In the latter case the court said:

"The rule that a security issued without a permit or in violation of the terms of a permit, is void under former section 12 of the Corporate Securities Act has been frequently declared, and must now be taken as well settled in this state. ... In 1931 ... a provision making such a security voidable was substituted for the old section (see Ballantine, California Corporation Laws, §513), but this has no application to the instant case." 19

14 See Note (1930) 18 CALIF. L. REv. 149, written with the cooperation of Donald A. Pearce, Esq., Deputy Commissioner of Corporations, criticizing many of the decisions and advancing the contention that the latter part of old section 12 of the Act must be interpreted to mean that if a security is issued in contravention of conditions in a permit, it is void. It is to be noted that old section 12 merely provided that if a security is issued by any company with the authorization of the Commissioner but not conforming in its provisions, if any, which it is required by the permit of the Commissioner to contain, it shall be void. As a matter of fact, the permit of the Commissioner never required any provision to be contained in a security.

15 Otten v. Riesener Chocolate Co., supra note 11.

16 Supra note 11.

17 (1931) 214 Cal. 89, 4 P. (2d) 145.

18 (1933) 219 Cal. 357, 26 P. (2d) 475.

$19 \mathrm{Ibid}$. at $359,26 \mathrm{P}$. (2d) at 476 . The court then cites a number of cases holding shares of stock to be "void" because of the absence of or nonconformity with the permit. An examination of each of the cases cited discloses that in every case there was a lack of permit and none of such cases squarely beld that securities issued prior to the 1931 amend- 
Despite the apparent inapplicability of many of the cases cited by the court in the Regan case, it must be assumed that that case definitely and authoritatively establishes the law of California and that any security issued prior to the 1931 amendment to the Act, in violation of the terms of the permit, is void.

It will be noted that the 1933 amendment to section 16 expressly provides that any security "sold or issued in nonconformity" with the terms of the permit shall be void. It would appear clear that the word "sold" as so used applies only to a sale of the security by the issuer and does not include resales by others than the issuer even though prohibited by the terms of a pernit. Thus, in case of violations of a condition subsequent of a permit requiring shares to be escrowed and forbidding their sale without the approval of the Commissioner, infractions would not render the security itself void but would only invalidate the sale.

This rule would appear to be clearly established by the case of Duntley $v$. Kagarise ${ }^{20}$ which was cited with apparent approval by the supreme court in Mary Pickford Co. v. Bayly Bros., Inc. ${ }^{21}$ although with reference to another point. Although the Duntley case involved

ment in violation of the terms of the Act were void. The Regan case clearly involved a condition precedent to issue, viz., a condition requiring the sale of securities for cash. Moreover, it is to be noted that the court in that case went no further than to hold that an issue of a security without a permit or in violation of the terms of the permit is void. It did not broaden this to include the sale of the security in violation of the terms of the permit.

${ }^{20}$ Supra note 11. The Duntley case involved shares wbich were issued in 1925, pursuant to a closed permit of the Commissioner of Corporations, to three original incorporators and were thereafter transferred, in violation of an escrow condition, to one of the promoters for his promissory note.

In an action by the two transferor-promoters against the third promoter on the promissory notes given by him as consideration for the transfer to him of such shares, the court denied recovery on the grounds that the conditions of the permit had been violated and refused to hold the transferee even though he had received all the benefits of the transaction and owned valid and valuable stock which he had not paid for. The court expressly held that the shares were originally validly issued pursuant to the permit. In replying to a contention that there is a distinction between sales of stock on the original issue thereof and sales of stock which had been validly issued and impounded in escrow, the court, while conceding that the stock had been validly issued pursuant to the permit, held that the sale was illegal even though the issue was not illegal. The court expressly pointed out that the validity of the stock itself was not involved and that the decision was therefore limited solely to the question of the legality of the sale. Recovery was denied, regardless of the defendant's participation in the violation and without requiring him to make restitution, on the grounds that there was a violation of a law intended for public benefit.

21 (1939) 12 Cal. (2d) 501, 86 P. (2d) 102. 
a transaction under old section 12, it would appear clear that the rule of that case should equally apply under present section 16, to all cases where the violation consists of a breach of a condition subsequent to issue contained in a permit. It would follow that no violation of a condition requiring the escrowing of shares would render the security itself void. Thus, in Braunstein v. Title Guarantee \& Trust Co. ${ }^{22}$ the supreme court held that negotiable notes, sold in violation of the terms of a permit requiring their deposit in escrow, are valid securities in the hands of innocent purchasers. ${ }^{23}$

Therefore, the rule (except possibly for the period from 1931 to 1933) established by the cases is that the security itself is void only if issued without a permit or in violation of a condition precedent to issue contained in the permit. Accordingly, statements contained in some of the cases, to the effect that the violation of any term of a permit renders the security void, are mere generalizations. There are many terms contained in permits which have nothing whatever to do with the issue of the security and are clearly designed to regulate conduct after the security has been issued. Indeed, some of such terms could only become operative in the event the security actually had been issued, such as a pure "escrow" condition forbidding resale without the consent of the Commissioner. And generally speaking, the distinction between a condition which is a condition precedent to issue, and a condition subsequent, is obviously clear. It would of course be absurd to contend that the violation of a pure condition subsequent would retroactively invalidate a security already validly issued.

\section{-Part Void-Part Valid.}

Only securities issued in nonconformity with the terms of a permit are void. It is to be noted that in certain cases some securities are properly issued in strict compliance with the terms of the permit, while other securities-sometimes of the same class-are issued in violation thereof. In such cases, it is only the securities which are issued in violation of the permit that are void. The securities which are issued in compliance with the terms of a permit are valid for all

22 (1932) 216 Cal. 780, 17 P. (2d) 104.

23 It is to be noted that even in the case of an "escrow" condition requiring approval of the Commissioner before securities may be resold, the vendor is not required to obtain a permit since the shares are clearly validly issued. He is only required to obtain the Commissioner's written approval which can ordinarily be obtained, if conditions justify it, by an informal application. 
purposes whether issued before or after those unlawfully issued. ${ }^{24}$ However, if both valid and invalid securities are sold under one contract, the contract is wholly void under the familiar rule that if any part of the consideration of the contract is illegal the contract is wholly void. ${ }^{25}$

Thus, the sale of shares in units, part of which are valid and part of which are invalid, taints the whole contract and all of such shares are void. ${ }^{28}$

\section{-Judicial Modification of "Void" Rule.}

Formerly, all of the decisions apparently announced the doctrine that a security issued without a permit, or in violation of the terms of a permit, is wholly void for all purposes. The cases mechanically applied the same rigid criterion as the courts do to overissued shares. Under the great weight of authority, overissued shares are absolutely void and the takers of them, even though they may be in the position of bona fide holders, acquire no rights as stockholders. ${ }^{27} \mathrm{Cook}^{23}$ states the rule as follows:

"[Overissued stock] is spurious and wholly void. This is the settled law, and it prevails equally whether the overissue is the result of accident or mistake, or want of knowledge of the law, or is due to fraud and intentional wrong-doing. The animus or intent of the parties to the overissue is not material. Overissued stock, no matter how overissued, represents nothing, and is wholly and entirely valueless and void. So rigid and well established is this rule that not even a bona fide holder of such stock can give to it any validity or vitality."

As stated in one of the California cases, void certificates of stock are not even choses in action and "would not have supported an action brought to recover money or value in the event of their transfer by the holder, because they were utterly worthless and invalid." ${ }^{29}$ Also, in the case of Becker v. Stineman ${ }^{30}$ there is a possible inference that an assignment by the original purchaser to a subassignee of a secur-

24 Kent v. Kent (1935) 6 Cal. App. (2d) 488, 44 P. (2d) 445.

25 Bank of Calexico v. Thompson (1931) 212 Cal. 388, 298 Pac. 808; Tatterson v. Kehrlein (1927) 88 Cal. App. 34, 263 Pac. 285.

(2d) 186.

28 L. A. Transfer Co. v. Ritz Carlton H. Co. (1935) 7 Cal. App. (2d) 154, 46 P.

2718 C. J.S. 710.

231 COOK, CoRporatrons (7th ed. 1913) $\$ \$ 292$ et seq.

29 Klinker v. Guarantee Title Co., supra note 12.

30 (1931) 115 Cal. App. 740, 2 P. (2d) 444. 
ity, void by reason of violation of the Act, would not transfer any right of action which the original purchaser had against the issuer. To the extent that these two cases contain any inference that an assignment, by an original purchaser to a bona fide subpurchaser of a security "void" by reason of violation of the Act, does not carry the right of action which the original purchaser had against the issuer, or to the extent that they hold that such bona fide subpurchaser could not enforce his rights as the holder of a valid security against the issuer, they are clearly erroneous and have been definitely overruled by the supreme court cases hereinafter mentioned.

Prior to 1932 it was generally believed that where securities were issued in violation of a permit or without one, the innocent purchaser could not enforce his rights under the contract but was only entitled to restitution. ${ }^{31}$ In other words, it was believed that such purchaser could only rescind or recover actual damages with interest but could not affirm since the securities were utterly void.

In the case of Eberhard v. Pacific Southwest L. \& M. Corp. ${ }^{32}$ decided in 1932, the California supreme court held that the parties were not in pari delicto and that the holders of notes issued without a permit could affirm the contract and foreclose the mortgages securing the notes they had received. The implications of this case were not fully recognized and a contrary view was expressed in a case under the Act arising in a federal court a few months later ${ }^{33}$ in which a purchaser of securities (oil royalties) was limited in a bankruptcy proceeding to bare restitution despite the fact that such securities had greatly enhanced in value.

The California supreme court in a number of subsequent decisions has followed the doctrine of the Eberhard case. ${ }^{34}$

The doctrine was also reaffirmed in the case of Robbins $v$. ?acific Eastern Corporation, ${ }^{35}$ in which the supreme court stated:

"In spite of the general language found in some of the cases that stock issued in violation of the Corporate Securities Act is 'void', it is

31 6A CAx. JUR. 561.

32 (1932) 215 Cal. 226, 9 P. (2d) 302.

33 Cecil B. De Mille Productions Co. v. Woolery, supra note 12.

34 See Western Oil \& Refining Co. v. Venago Oil Corp. (1933) 218 Cal. 733, 24 P. (2d) 971 ; Braunstein v. Title Guaranty \& Trust Co., supra note 22 ; Security-First National Bank v. J. G. Ruddle Properties, Inc. (1933) 218 Cal. 435, 23 P. (2d) 1016; Domestic \& Foreign Pet. Co. v. Long (1935) 4 Cal. (2d) 547, 51 P. (2d) 73. See also, White v. Cascade Oil Co. (1936) 14 Cal. App. (2d) 695, 58 P. (2d) 994; Julian v. Schwartz (1936) 16 Cal. App. (2d) 310, 60 P. (2d) 887.

35 (1937) 8 Cal. (2d) 241, 277, 65 P. (2d) $42,61$. 
well settled that that act belongs to that type of statute which is aimed at one class for the protection of another class. In other words, the prohibitions and penalties of the Corporate Securities Act are levelled against the seller and not against the buyer. This is well settled ..." (citing the cases above mentioned).

The basis of the doctrine is stated in the Eberhard case as follows:

"The seller and the purchaser are therefore in no sense in pari delicto where this provision is violated. The fact that the transaction may be void at the behest of the purchaser is not to allow a premium for a real wrong done by the seller. The fundamental maxim that 'no one can take advantage of his own wrong' (sec. 3517, Civ. Code) and other kindred principles immediately recur to the mind." 36

It is therefore apparent that overissued stock does not furnish an exact parallel to securities issued in violation of the permit provisions of the Act. In the case of overissued stock the buyer cannot affirm and it is not possible for the corporation to admit him as a stockholder. He can only recover damages. ${ }^{37}$

Therefore, in California, despite the general language found in many of the earlier cases to the effect that securities issued in violation of the permit provisions of the Act are wholly and absolutely void-even as to a bona fide buyer-such securities are held to be merely voidable at the behest of innocent original purchasers or subsequent assignees whenever necessary for their protection.

Here, again, the courts have applied a pragmatic test to carry out the purpose and spirit of the Act. The test would seem to be the reaching of a sensible result under the facts and circumstances of each case and not the application of a rigid criterion. The rule would appear to be that the courts will declare securities issued without a permit or in violation of a permit absolutely void as between issuer and purchaser (or subpurchaser) whenever it is to the detriment of the purchaser to declare them valid, and will declare them enforceable whenever it is to the benefit of the purchaser. ${ }^{38}$

The rule applies not only to original purchasers but also to successive transferees or subassignees, and is available even to a bona fide purchaser without notice of nonnegotiable securities who takes from a purchaser who is in pari delicto with the issuer. ${ }^{39}$

36 Supra note 32 , at 228,9 P. (2d) at 303.

37 National Bank of Webb City v. Newell-Morse Royalty Co. (1914) 259 Mo. 637, 168 S. W. 699 ; Allen v. South Boston R. Co. (1889) 150 Mass. 200, 22 N. E. 917.

38 See Note (1937) 10 So. CaLIF. L. REv. 483.

39 Domestic \& Foreign Pet. Co. v. Long, supra note 34. 
The doctrine making the transaction voidable at the option of the purchaser, even though the statute has declared all transactions in violation thereof void, is not peculiar to California but represents a modern trend. ${ }^{40}$

Various other familiar types of statutes which outlaw sales and other transactions visit their penalties only upon one party to the transaction. Thus, various liquor laws ${ }^{41}$ forbid sales of liquors but not their purchase. Usury laws also fall "within that class of statutes in which, although the contract is declared void, it is voidable only at the election of the oppressed party . ..."12

\section{True Nature of Civil Liability Under the Permit Provisions of the Act.}

In retrospect, the confusion and conflict in the multitude of cases as to the basic theory of liability under the Act seem wholly incomprehensible. It is believed that the chief explanation of this obfuscation lies in the fact that practically all of the earlier cases involved actual fraud-and usually gross fraud-and not a simple, innocent violation of the Act. But the true nature of civil liability under the permit provisions of the Act can only be tested and measured by a case where there is a bare, honest violation of the Act, without the slightest taint of actual fraud. Consequently, the following analysis will be directed to such a suppositious case. In such a case there is no actual misrepresentation of any kind, either conscious or unconscious. However, some of the cases hold that the law raises an implied misrepresentation to the effect that a permit has been secured. As hereinafter discussed, it is believed that even implied misrepresentation is not a necessary element of the liability.

As stated in the introduction to this article, the courts in construing the Act have drawn on old common-law principles of deceit, negligence and warranty. Unfortunately, the analogies employed have not been perfect. There was, of course, no special common law applicable to securities. "Instead general tort and contract law developed

10 Note (1937) 23 IowA L. REv. 102, 113: "Since the question first arose, a majority of states have held sales and contracts to sell securities made in violation of the statute void, if the statute was silent as to the remedy; but the more recent tendency has been to make the transaction voidable at the option of the purchaser even if the statute has declared all transactions in violation thereof void." The author of the note lists, in addition to California, decisions from Iowa, Minnesota, Wisconsin and Virginia.

11 Cf. People v. Winkler (1916) 174 Cal. 133, 162 Pac. 109; U. S. v. Farrar (D. Mass. 1930) 38 F. (2d) 515, af'd, (1930) 281 U.S. 624.

42 Matthews v. Ormerd (1903) 140 Cal. 578, 582, 74 Pac. 136, 138, quoting from Reading v. Weston (1829) 7 Conn. 409. 
largely in connection with other transactions was applied piecemeal to securities cases as they came before the courts. ... The fortuitous incident of choice of remedy by plaintiff's counsel was frequently given major importance." ${ }^{43}$ In the main, the courts in dealing with securities cases under the old common law applied concepts of deceit, negligence or warranty liability.

The problem of liability for unconscious misrepresentation, wholly unrelated to statutory liability, has probably evoked the thought and labors of as many legal scholars of the highest calibre as any other question in modern jurisprudence. ${ }^{44}$

The House of Lords, in Derry v. Peek, ${ }^{45}$ settled the English rule to the effect that an action of deceit cannot be maintained by a plaintiff who has been misled into a disadvantageous financial or commercial venture unless the defendant is guilty of conscious misrepresentation.

A great number of the American jurisdictions have rejected this doctrine and permit recovery under certain circumstances against a defendant who honestly believes that he has told the exact truth. The element of knowledge of the defendant of the falsity of his statement has been subjected to considerable variation..$^{46}$ Some of the jurisdictions which permit recovery against a defendant for honest misrepresentation rest the liability on negligence, while others base the liability on warranty. As Bohlen points out, in jurisdictions which hold a defendant for honest though negligent misrepresentation, the courts while purporting merely to extend tort liability are, in fact, recognizing a new basis of liability substantially different from deceit, negligence, or warranty. If it be a tort liability at all, it is substantially an absolute liability regardless of fault, and neither wilful intent nor negligence is essential. On the other hand, it is strictly not an extension of the law of warranty since, if it were, only those who are parties to a sale or other contract induced by the warranty would be held liable thereon.

Several of the leading commentators who have pointed out the false analogies pursued by the courts maintain that clear discrimina-

43 See Shulman, Civil Liability and the Securities Act (1933) 43 YaLE L. J. 227.

44 E.g., Bohlen, Misrepresentation as Deceit, Negligence, or Warranty (1929) 42 HARv. L. REV. 733; Shulman, loc. cit. supra note 43, and authorities cited; Smith, Liability for Negligent Language (1900) 14 HARv. L. REv. 184; Williston, Liability for Honest Misrepresentation (1911) 24 ibid. 415.

45 (1889) 14 App. Cas. 337.

16 See Shulman, loc. cit. supra note 43. 
tion must be drawn between liability for intended wrongs, liability for wrongs of negligence, and absolute liability unconnected with fault or wrongdoing. On this analysis it is urged that deceit should properly be confined to cases of intentional lying or actual fraud, negligence to cases of unintended misrepresentation, and warranty to cases where absolute liability is imposed.

It is believed that liability under the Act is not essentially either liability for deceit or for negligence, nor is it strictly a warranty liability. It is more accurately a liability created by statute, absolute in nature, regardless of the scienter of the seller, reliance of the buyer, or causation, and it would appear to be mere slavery to old terms to attempt to characterize it by any single common-law concept of liability.

Deceit, generally, can only consist of intentional wrong. There must be intent to deceive. Moreover, in actual fraud the plaintiff must allege and prove reliance, and it is clear that one who has actually investigated the truth of the representation and is given full and fair facilities for doing so and who acts upon his own knowledge cannot be said to rely upon the representation. ${ }^{47}$ It is equally clear that liability arises under the Act even though there be no dishonest or wilful misrepresentation. Thus, it is well established that good faith on the part of the seller is no defense. ${ }^{48}$ In short, scienter would appear to be wholly irrelevant. Moreover, reliance on the part of the buyer, which is an essential element in fraud, is also wholly irrelevant in cases arising under the Act. It has been repeatedly held that the buyer may recover damages notwithstanding his knowledge of the seller's lack of, or noncompliance with, the permit. ${ }^{49}$

Many of the earlier California cases $^{50}$ hold that in every case of

47 Hayward v. Widman (1933) 133 Cal. App. 184, 23 P. (2d) 762.

18 People v. McCalla, supra note 2; El Clara Oil etc. Co. v. Daugherty (1936) 11 Cal. App. (2d) 274, 53 P. (2d) 1028. In the latter case the court said: " . . there are many assertions . . . that the plaintiff and its agents acted in good faith. However, good faith is not an element mentioned in the statute. It prohibits the doing of certain acts without first obtaining from the defendant [corporation commissioner] a permit authorizing those acts. As it does not mention good or bad faith such factors are not involved." Ibid. at 281, 53 P. (2d) at 1031.

49 Randall v. California L. B. Syndicate (1933) 217 Cal. 594, 20 P. (2d) 331; Duntley v. Kagarise, supra note 11.

50 Pollak v. Staunton (1930) 210 Cal. 656, 293 Pac. 26; First National Bank v. Thompson (1931) 212 Cal. 388, 298 Pac. 808; Randall v. California L. B. Syndicate, supra note 49; Gillis v. Pan American Western Pet. Co. (1935) 3 Cal. (2d) 249, 44 P. (2d) 311 ; Boss v. Silent Drama Syndicate, supra note 12; MacDonald v. Reich \& Lievre, 
violation of the permit provisions of the Act implied fraud is conclusively presumed. But practically all such cases involved actual fraud in addition to a violation of the permit provisions of the Act. Actual fraud can always be dealt with vigorously under any and all circumstances, but the drastic consequences of actual fraud should not, in the absence of a clear legislative declaration, be applied under all circumstances to a field of absolute liability penalizing innocent though mistaken conduct. The same considerations which moved the House of Lords in Derry v. Peek. to balk at the idea of branding responsible business men with the serious charge of fraud, where there is clearly no conscious or dishonest misrepresentation, are clearly applicable here.

The California supreme court, in the leading case of Mary Pickford Co. v. Bayly Bros., Inc., ${ }^{52}$ and its companion case of Bartlett v. Suburban Estates, Inc. ${ }^{53}$ overruled all of the earlier cases which were decided upon the theory that the buyer of securities sold in violation of the permit provisions of the Act has a cause of action for fraud under all circumstances. It is therefore now authoritatively established that liability for a violation of the Act, uncoupled with actual fraud, does not sound in fraud.

Moreover, it appears clear that liability for violation of the Act is not strictly a tort liability for negligence. The liability attaches even though the issuer uses due care upon carefully collected data. ${ }^{54}$ Thus, even though a seller is expressly advised by the Commissioner of Corporations that no permit is required, nevertheless, the issuer is liable..$^{55}$ Moreover, if the liability were based on negligence, logically the contributory negligence of the buyer would be a defense. ${ }^{56}$ It is clear that it is not in cases of violation of the Act. Even though the purchaser himself has full knowledge of the violation, or fails to use available means of information whereby he could protect himself, he is nevertheless not barred from recovery. Therefore, the issuer who violates

Inc. (1929) 100 Cal. App. 736, 281 Pac. 105; Klombies v. Weeks Poultry Community (1932) 121 Cal. App. 175, 8 P. (2d) 940.

51 Supra note 45.

52 (1939) 12 Cal. (2d) 501, 86 P. (2d) 102.

53 (1939) 12 Cal. (2d) 527, 86 P. (2d) 117.

$54 \mathrm{It}$ is interesting to note that the Act is much more severe in many respects than the Securities Act of 1933. Under the latter act, due diligence and the exercise of reasonable care are defenses under several circumstances. $C f$. sections 11,12 , and 15 of that act.

65 Bartlett v. Suburban Estates, Inc., supra note 53; Boss v. Silent Drama Syndicate, supra note 12 .

56 Bohlen, op. cit. supra note 44 , at 740 . 
the Act is liable even though wholly free from negligence and even though he exercises the judgment of a reasonable man. However, although liability attaches in such instances where the issuer is wholly without fault, the question whether the issuer exercises due care may affect the period of the limitation of actions, as hereinafter discussed.

The supreme court, in the Pickford case, while it rejected the fraud theory of liability, rested liability under the Act on implied warranty. It is believed that the liability is not a true extension of the idea of warranty. It undoubtedly has some of the elements of warranty. It is absolute in nature, without regard to wrongdoing, and scienter, as in warranty, is wholly immaterial. In California, a vendor of personal property is liable in warranty to his immediate vendee, whether he acted in bad faith or not. ${ }^{57}$ Liability under the Act is also similar to warranty in that causation need not be proved. In warranty cases, at least in California, the seller need only allege that he relied on the representation, not that he suffered any loss thereby. ${ }^{58} \mathrm{But}$ in at least three respects, liability under the Act is essentially different from warranty.

First, warranty does not run in favor of subassignees or remote purchasers, the general rule being that warranty does not run in favor of any but an immediate purchaser. ${ }^{50}$ As commonly stated, "there can be no warranty where there is no privity of contract." ${ }^{\circ}$ This is also the California rule, and, in warranty cases, the vendee can recover only from his immediate vendor and from no other. ${ }^{01}$ On the other hand, there is no requirement of privity to attach liability under the Act. Thus, it is clear that subassignees can sue the issuer. ${ }^{02}$

Secondly, in warranty cases only those who are parties to a sale or other contract induced by the warranty are liable. ${ }^{63}$ On the other hand, it is clear that liability attaches under the Act to persons who merely "aid" in the transaction and are not actual parties to the sale, as demonstrated by the cases hereinafter discussed.

Thirdly, under the majority rule, there is no warranty when the

57 Jeffers v. Easton, Eldridge \& Co. (1896) 113 Cal. 345, 45 Pac. 680; 22 CAI. JUR. 960.

58 Vulcan Fire Ins. Co. v. Jorgensen (1917) 33 Cal. App. 763, 166 Pac. 835.

591 WILLISTON, SALES (2d ed. 1924) $\$ 244$.

60 Note (1929) 42 Harv. L. Rev. 414 ; (1931) 44 ibid. 643 ; Bohlen, op. cit. supra note 44, at 743; Shulman, loc. cit. supra note 43.

61 Pezel v. Yerex (1922) 56 Cal. App. 304, 205 Pac. 475.

62 Boss v. Silent Drama Syndicate, supra note 12.

63 Bohlen, loc. cit. supra note 44. 
sale is void for illegality. ${ }^{64}$ Thus, there can be no warranty in the case of a prohibited sale of intoxicating liquor ${ }^{63}$ or prohibited sale on Sunday.$^{66}$ However, under the Act liability is imposed for the very reason that the sale or transaction is illegal.

Thus, it would appear that liability under the Act is a new type of liability imposed by statute, absolute in nature, and scienter, reliance, materiality and causation are all irrelevant. Moreover, it is believed that such liability runs to successive purchasers and is not limited only to those who are actual parties to the sale.

The Act renders illegal conduct on the part of the issuer that was perfectly lawful prior to its enactment. It mechanically lays down a rule of absolute rigidity. It automatically renders it unlawful to sell certain securities without having obtamed a permit, and stops short there, without inquiring whether there was misrepresentation, or any other wrongdoing, or even damage. It does not undertake " . . to deal with the question of abstract justice in the particular case." ${ }^{\text {67 }}$ As a consequence, innocent bona fide transactions may also be caught in the net of the law.

While the liability is one created by statute, it seems clear that it is not a "statutory penalty". Generally speaking, an action to enforce a statutory penalty does not survive death and is not assignable. And it is interesting to note that the Wisconsin supreme court, conceding itself clearly bound by the federal statute itself without reference to state rules, held that the Securities Act of 1933 is penal in nature and that a cause of action arising thereunder does not survive and is not assignable. ${ }^{88}$ It appears that a contrary rule has been established in this state as to causes of action arising under the Corporate Securities Act. ${ }^{69}$ Moreover, the general rule under the various state securities acts is that the cause of action to enforce civil liability thereunder survives and is assignable. ${ }^{\text {io }}$

It is interesting to compare civil liability under the Act with that under the Securities Act of 1933, as originally enacted. Of the latter act, it has been stated:

64 Note (1929) 42 HaRv. L. REv. 414, 415.

65 Bolliver v. Monnat (1927) 224 N. Y. Supp. 535.

68 Grapico Bottling Co. v. Ennis (1925) 140 Miss. 502, 106 So. 97.

6r Wendt v. Fischer (1926) 243 N. Y. 439, 444, 154 N. E. $303,304$.

68 Wogahn v. Stevens (1940) 236 Wis. 122, 294 N. W. 503, 133 A. L. R. 1033.

69 Auslen v. Thompson (1940) 38 Cal. App. (2d) 204, 101 P. (2d) 136, hearing den. (May 27, 1940).

70 Note (1941) 133 A. L. R. 1038. 


\begin{abstract}
"In several important particulars the Act departs from the commonlaw civil liability. (1) A purchaser of securities may sue the persons named even though he purchased in the market after the securities had gone through several hands. (2) He may sue even though he never read or knew of the untrue or misleading statement prior to his purchase. (3) He need not establish a causal connection between the untruth and his loss, nor is he barred if such causal connection be disproved. (4) Scienter and its variations are definitely supplanted by the notions of insufficient investigation and unreasonable grounds for belief; and the standard of reasonableness is, not that of 'the ordinary, prudent man under the circumstances,' but that required of a fiduciary. (5) The burden is on the defendant to establish the reasonableness of his investigation and belief, rather than on the plaintiff to establish the contrary. (6) A measure of damages different in some respects from that under the common law is provided... The most striking innovation is ... dispensing with any requirement of privity and permitting 'any person acquiring' the security to sue the persons enumerated." 11
\end{abstract}

Since its original enactment, the Securities Act of 1933 has been softened by various ameliorating amendments, which either broaden the defense of exercise of reasonable care by the defendant or lack of reliance on the part of the plaintiff, or permit a defense if causal connection is disproved. ${ }^{72}$

The basis of civil liability under the federal act is not nearly as severe as that under the Corporate Securities Act. Under the former there must be an untrue or misleading statement of a material fact. Under the latter the liability is absolute.

However, while there is no requirement of scienter, reliance, privity or causation to impose liability under the California Corporate Securities Act, the absence of certain of these elements does have some bearing on questions as to parties who are liable, parties who are entitled to recover, and on questions of defenses.

\title{
PERSONS LIABLE
}

\section{General.}

In contrast to sections 11 and 12 of the Securities Act of 1933, the Corporate Securities Act does not specify the persons who are civilly liable for a violation of the permit provisions of the Act. Its express provisions merely forbid, in section 3, an issuer ("company") from selling a security of its own issue without a permit, and, in sec-

71 Shulman, op. cit. supra note 43 , at 248.

$72 C f$. amendments to sections 11 and 15 . 
tions 17 and 18, impose criminal penalties on the issuer and on every officer, agent or employee of the issuer and on every other person who knowingly aids in the issue or sale, where there is an issue or sale in violation of the permit provisions of the Act.

The Act imposes a statutory duty to obtain a permit and to observe strictly the terms of the permit before securities may be issued. The question as to which persons are civilly liable for violation therefore resolves itself simply to the question: upon whom is the statutory duty placed? It is clearly imposed on the issuer itself and on all officers, directors and agents of the issuer who participate in the issue. Thus even independent institutions which act as transfer agents or registrars may be liable, since they are in an agential capacity and "aid" in the issue. But is the burden of ascertaining that a permit has been obtained and complied with also put upon persons who are neither agents nor affiliates of the issuer, such as underwriters, or even dealers conducting transactions in the secondary market? As discussed in a subsequent part of this article, underwriters and dealers are subject to all of the dealer regulation provisions of the Act and must be licensed and comply with various other requirements. Are they also under a statutory duty to see that a permit has been obtained? There is a dictum in the opinion of the supreme court in the Pickford case $^{73}$ to the effect that underwriters are subject to the same liability as issuers. Also, there are sweepingly general statements in certain opinions of the district courts of appeal hereinafter discussed, which by way of dictum state that there is a burden on every seller of a security to see that a permit has been obtained and that such security can be lawfully sold. In the following discussion the question will be examined critically as to each category of sellers.

Issuer.

The issuer is under all circumstances liable for the issue of its own securities in violation of the permit provisions of the Act. As previously stated, this liability is absolute. It is no defense that the issuer acted with due care or under an honest mistake or in good faith or that the purchaser had full knowledge of the violation, since the purchaser is not in pari delicto with the issuer. Except only as to an initial purchaser who is equally culpable with the issuer, the issuer who violates the Act has only the defense of the bar of the statute of limitations.

To Mary Pickford Co. v. Bayly Bros., Inc., supra note 52. 
It is also believed clear, for the reasons stated under a subsequent caption, that the liability of the issuer runs not only to initial purchasers but extends as well to any person who acquires the security. The common-law requirement of privity is not essential and subpurchasers may sue the issuer who has violated the Act. ${ }^{74}$ However, there is reasonable doubt whether liability exists (in the absence of actual fraud or causation) with respect to any purchaser, whether initial or remote, who no longer owns the securities.

Directors, Officers and Agents of the Issuer.

All directors, officers and agents of the issuer, who personally participate or aid in any way in the issue of a security in violation of the permit provisions of the Act, are personally liable. ${ }^{\text {is }}$ It is immaterial whether or not such persons receive any part of the purchase price or whether they personally profit in the transaction. ${ }^{78}$ It has been stated that participation by any such persons in the issuance of the stock amounts in law to a representation that such stock is valid and genuine. ${ }^{77}$ More accurately, such personal liability of a participating director or officer would appear to be predicated solely upon the fact that the statute has been violated. It is created exclusively by statute even though the Act does not expressly provide for such personal liability. ${ }^{78}$ The Act imposes the statutory duty to obtain a permit on the participating officers, directors and agents as well as on the issuer itself. However, unlike the Securities Act of 1933, which even imposes liability on inactive or dummy directors, personal liability is not imposed under the Act on an officer or director unless he has actively participated in the wrong. ${ }^{\text {? }}$

Even as to participating officers and directors, the cases have applied inconsistent measures of damage, dependent upon the form of remedy chosen. Thus, if directors who personally receive some of the consideration paid for the illegally issued securities are held liable

74 In this respect the Act is similar to section 11 of the Securities Act of 1933 which is recognized as being novel in its extension of the issuer's absolute liability to subpurchasers.

${ }^{75}$ Mary Pickford Co. v. Bayly Bros., Inc., supra note 52; Boss v. Silent Drama Syndicate, supra note 12.

${ }^{76}$ Auslen v. Thompson, supra note 69; Woods v. Deck (C. C. A. 9 th, 1940) 112 F. (2d) 739 (president of issuer who negotiated sale of mvalid securities and received the money therefor, whether as agent or otherwise, is liable).

i7 Randall v. California L. B. Syndicate, supra note 49.

78 Cf. Note (1943) 144 A.L. R. 1356.

79 Walker v. Harbor Realty Etc. Corp. (1931) 214 Cal. 46, 3 P. (2d) 557; Mary Pickford Co. v. Bayly Bros., Inc., supra note 52. 
in an action for money had and received, each is severally liable only for the portion of the consideration he actually received. ${ }^{80}$ However, if a director who receives nothing is sued in an action for damages, he is liable for the full amount the buyer paid. ${ }^{81}$

Since the action is not one to enforce a statutory penalty, it survives and may be enforced against the estate of a deceased officer or director who participated in the illegal issue. ${ }^{82}$

As heretofore indicated, persons who are agents, although not directors, officers or einployees of the issuer, and who participate or aid in the issue, are also liable. Thus, in the Pickford case, ${ }^{83}$ the California Trust Company, although not the issuer of the specific securities involved, was also held liable because of its participation in the "general scheme" to issue the securities. It would appear that transfer agents and registrars would be equally liable. In this respect the Act is much more severe than the Securities Act of 1933. It would appear clear that transfer agents and registrars would not be held to the liability created by the latter act, under which liability is essentially based upon an untrue or misleading statement of a material fact and is not as absolute in nature as the liability under the Corporate Securities Act.

\section{Underwriters.}

The Act is wholly silent on the question of the liability of an underwriter where there is violation of the permit provisions of the Act, and no case has been found that squarely considers the question. The supreme court, in its opinion in the Pickford case, stated:

\footnotetext{
"Whenever, therefore, an issuer or underweriter of securities offers them for sale to the public, he impliedly represents that the applicable provisions of law have been complied with." ${ }^{84}$ (Italics added.)
}

No underwriter was involved in the case, and accordingly the statement is pure dictum insofar as it relates to underwriters. It is believed that under the Act a true underwriter is not an agent of the issuer, as he may be under the Securities Act of 1933. He acts as a principal in purchasing securities directly from the issuer, for his own account and risk, with the view of reselling thein to others. Since an under-

\footnotetext{
80 Pollak v. Staunton, supra note 50.

81 Randall v. California L. B. Syndicate, supra note 49.

82 Auslen v. Thompson, supra note 69.

83 Mary Pickford Co. v. Bayly Bros., Inc., supra note 52.

84 Supra note 52 , at $519,86 \mathrm{P} .(2 \mathrm{~d})$ at 111.
} 
writer actually acquires title to the securities for his own account, it is arguable that, like any other initial purchaser, he is not in pari delicto, and should not be held to the same liability as the issuer.

However, regardless of whatever rights the underwriter may have against the issuer, the question arises whether an underwriter, because of the very nature of the issuer-underwriter relationship, is liable where there is violation of the Act. The problem is by no means simple and must be considered on the various grounds hereinafter mentioned.

Although the underwriter is not strictly an agent of the issuer, he is, in the eyes of the public at least, a sponsor of the new securities, and in a measure he does "aid" or "participate" in the general scheme of the issue of the securities, and indeed makes such issuance possible. An underwriting agreement is far more than a mere subscription agreernent. By reason of his effective command of the situation, an underwriter is able, to a large extent, to dictate the terms and conditions of the underwriting agreement. It is standard practice to include among the conditions of the underwriters' obligation, a requirement that the underwriters be furnished with an opinion of counsel as to the legality of the securities. Any underwriter who enters upon an underwriting without requiring such opinion clearly does not observe the customary standards of care of underwriters. A resale by him where there has been permit violation could scarcely be in good faith. The mere fact that an underwriter himself cannot obtain a permitwhich can only be obtained by the issuer-might not relieve him from the duty of seeing that a permit is obtained and complied with, any more than similar considerations relieve transfer agents and registrars from such duty. Practically speaking, he is in a position to compel the issuer to obtain a permit.

Moreover, wholly aside from the question of whether an underwriter "aids" or "participates" in the issue of the securities, it is possible that he would be held to imputed knowledge of violation, and his liability might be rested on this ground alone. It is difficult to conceive how an underwriter could actually be ignorant of the permit requirements of the Act. Any such lack of knowledge would clearly appear to be based on recklessness and not upon the exercise of reasonable care. On this ground alone, and wholly aside from the question of violation of the Act, an underwriter might be held liable for breach of the implied warranty that he has no knowledge of any fact which would impair the validity of the securities sold by him. 
Therefore, regardless of what theory is chosen, it is possible that the courts might hold that an underwriter reselling the securities is liable for violation of the permit provisions of the Act. Even so, it is uncertain whether such liability would be coextensive with that of the issuer itself and thereby run to remote purchasers, or whether it would be grounded solely on breach of an implied warranty of lack of knowledge of invalidity and consequently run only to the immediate purchaser from the underwriter.

\section{Dealers and Other Vendors Not Affliated With the Issuer.}

Are bona fide dealers and other vendors reselling personallyowned securities originally issued in violation of the Act, who are not underwriters and who are in noway acting on behalf of the issuer, under the duty of ascertaining whether a permit has been obtained and complied with? The position of such sellers is quite different from that of the underwriter who directly negotiates and contracts with the issuer in connection with a new original issue. Aside from the corporation-stockholder relationship, such dealers and other vendors have no contractual dealings with the issuer.

No California case has been found which squarely deals with the problem, either in respect of a dealer, or of an individual selling personally-owned securities issued by another. ${ }^{85}$

The district court of appeal, in the case of People v. Dean, ${ }^{\text {se }}$ used

85 The question was involved in Boss v. Silent Drama Syndicate, supra note 12. In that case Boss had purchased from one L.Y. Keady, for $\$ 500$ cash, five shares in a common-law trust, of the par value of $\$ 100$ each. Boss sued the trust and two of its trustees in an action in deceit for the recovery of damages. He did not sue Keady and the record is clear that he made no attempt to recover from Keady. On appeal, one of the principal defenses urged by the defendant was that Boss had made no attempt to hold Keady. The plaimtiff argued that the vendor, Keady, was under no liability since he had acted in good faith. While the decision does not expressly pass on this point, it does uphold the judgment against the defendants, and in view of the elaborate argument on the point contained in the briefs, the decision would appear to be of some authority in Cahifornia for the rule that a bona fide vendor is not liable to his purchaser. The Boss case was decided on the theory that the security was wholly void for all purposes, and on the theory of conclusive presumption of fraud, both of which theories have subsequently been rejected by the Cahifornia supreme court. For these reasons, the weight of the decision in the Boss case may be somewhat lessened.

86 (1933) 131 Cal. App. 228, 21 P. (2d) 126. In that case two defendants were jointly charged with violation of the Act for selling securities for which no pernit had been obtained. Dean, one of the defendants, was secretary for the trustee-issuers and countersigned the certificates involved. The other defendant, a Mrs. Ray Seidlitz, owned the mining property which was to be the first property to be operated by the issuers. The trial court granted motions to dismiss the counts charging violation of the Act on the 
sweepingly broad language to the effect that there is a burden on every seller of a security to see that a permit has been obtained and that such security can be lawfully sold. The language used in that case was much broader than was necessary for the result reached. The case palpably involved a sale of securities upon an original issue.

In the subsequent case of People v. Stowell, ${ }^{87}$ which also clearly involved an original issue, the district court of appeal, after citing the Dean case with approval, stated that "The burden rested upon appellant to ascertain at his peril whether his acts were in violation of the statute."

While undoubtedly every agent who acts for the issuer-and possibly also an underwriter-is under the duty of ascertaining that a permit has been obtained and complied with, it would seem clear that independent dealers and brokers and individual owners making resales of securities in the ordinary course of business are not under such duty. Such a rule would impose an impossible and harsh burden on them. They themselves could not obtain a permit, and moreover, have no power to compel an issuer to obtain a permit.

Accordingly, it is believed, for the reasons hereinafter outlined, that independent dealers and brokers need only obtain a "broker's" license and otherwise comply with the dealer regulation provisions of the Act, and individuals selling their personally-owned securities need not even do that.

The majority rule at common law was that in a sale of securities the seller impliedly warrants that they are genuine and are legally

ground that there was no evidence introduced to show that no permit was obtained. The appellate court held that the burden of negativing the issuance of such a permit is not required of the prosecution, but the burden is upon the defendants to prove the affirmative thereof as a matter of defense, and that it is immaterial that the permit would not have been issued to them but to the issuer of the security. The court beld that the defendants were not being charged as being issuers of securities or as acting as agents or brokers for the issuer, but with violating section 18 of the Act in selling a security for which no permit was obtained authorizing the issuance thereof. The court said: "The purpose of the act is to put the burden upon one selling a security to see that it can be lawfully sold." The holding of the case, when limited to the actual facts, was undoubtedly sound since the case clearly involved an original issue in violation of the Act, and the only person held was Dean who actively participated in the original issue, actually countersigned the certificates, and clearly must lave known that no permit had been obtained. However, the implications of the language used by the court are much too broad.

87 (1941) 45 Cal. App. (2d) 580, 114 P. (2d) 614. In that case the defendant participated and aided in the sale of securities on an original issue and the record was clear that he did not act in good faith. 
what they purport to be. ${ }^{88}$ The California supreme court, in its decision in the Pickford case, ${ }^{89}$ states that this common-law rule was universal. It is believed that this statement is much too sweeping since there would appear to be a conflict of authority in the various jurisdictions as to the common-law rule. ${ }^{90}$

Regardless of the general rule at common law, it is clear that in California, at least up to 1931, a bona fide vendor of securities did not impliedly warrant that they were genuine and legally what they purport to be by reason of the provisions of section 1764 and former section 1774 of the California Civil Code. Former section 1774 provided that "one who sells or agrees to sell an instrument purporting to bind anyone to the performance of an act, thereby warrants that he has no knowledge of any facts which tend to prove it worthless, such as ... its invalidity for any cause." This section limited the rule of the common law and was held to be exclusive. ${ }^{91}$ It was repealed in 1931. The California rule was stated in one of the leading cases as follows:

“... If an invalid negotiable instrument ... be presented for sale, both parties being equally innocent, the purchaser cannot recover. ... The distinction, then, is, that in the other states the sale carries a warranty of genuineness; in this state the sale carries merely a warranty that the seller has no knowledge of defects." 92

It is therefore clear that, prior to 1931, a bona fide vendor, not affiliated with the issuer, who resold securities issued in violation of the pernit provisions of the Act, was not liable either to his immediate purchaser or to any subpurchaser. This rule was equally applicable to negotiable and nonnegotiable choses in action and to licensed dealers as well as to individuals selling personally-owned stock. It would also appear clear that the same rule has continued to apply

88 Meyer v. Richards (1896) 163 U.S. 385 ; Restatement, Contracts $\$ 175-1$ (b) (c) ; see 12 Fletcher, Cyc. Corps. (Perm. ed. 1932) $\$ 5616$.

89 Mary Pickford Co. v. Bayly Bros., Inc., supra note 52.

90 See 1 CoOK, Corporatrons (7th ed. 1913) $\$ 296$, stating the common-law rule as to liability of vendors on resales of overissued stock as follows: "In the absence of fraud, the purchaser of overissued and spurious stock cannot hold the vendor liable thereon. The bona fide vendor can be held to warrant only his own title to the shares, not the right of the corporation to issue them." 18 C.J.S. 717 states that in the absence of a warranty a bona fide vendor of overissued securities is not liable.

91 Sutro v. Rhodes (1891) $92 \mathrm{Cal} .117,28$ Pac. 98; Harvey v. Dale (1892) 96 Cal. 160, 31 Pac. 14; Crocker-Woolworth Bank v. Nevada Bank (1903) 139 Cal. 564, 73 Pac. 456.

92 Crocker-Woolworth Bank v. Nevada Bank, ibid. at 585, 73 Pac. at 464. 
since 1931 with respect to negotiable instruments by reason of the provisions of Civil Code section 3146, and to stock certificates by reason of section 330.11(c) of the Uniform Stock Transfer Act, which merely bind a transferor of a negotiable instrument or stock certificate to the implied warranty that he has no knowledge of any fact which would impair its validity.

It has been contended ${ }^{93}$ that the Pickford case is authority for the rule that since 1931 the seller of a nonnegotiable instrument in California impliedly warrants title, genuineness and validity. It is believed that such contention construes the holding of the Pickford case much too broadly. It is a familiar rule "that the language of an opinion must be construed with reference to the facts presented by the case, and the positive authority of the decision is coextensive only with such facts." ${ }^{91}$ The Pickford case involved the original parties to an issue transaction, and the "warranty of validity" was applied only to those who participated in the original issue of securities. The case did not present a situation between a vendor and a subpurchaser. The court ușed the following language:

\begin{abstract}
"Although ... the common-law warranty applicable to a sale of securities was limited in this state, nevertheless because of the provisions of the Corporate Securities Act ... in effect at the time of the transaction here in controversy, a seller of securities necessarily warranted that the duties therein imposed upon him had been performed. Such a warranty is based upon the obligation to secure a permit which the law enjoined upon the seller."95 (Italics added.)
\end{abstract}

If the word "issuer" is inserted in lieu of the word "seller" in both places in the above-quoted passage, the true rule of the Pickford case becomes readily apparent. It is only the issuer (including within that term all persons who aid or participate in the issue) who is charged under the statute with the obligation of securing a permit. There is no such statutory duty on a vendor unaffiliated with the issuer. As heretofore pointed out, the permit provisions of the Act do not apply either to dealers or individual owners making resales of securities. It would therefore appear axiomatic that no such dealer or individual owner who resells securities issued without a permit should be held to any implied warranty that a permit has been obtained. The absolute lia-

93 (1939) 27 CatrF. L. Rev. 477.

94 River Farms Co. v. Superior Court (1933) 131 Cal. App. 365, 369, 21 P. (2d) 643,645 .

95 Mary Pickford Co. v. Bayly Bros., Inc., supra note 52, at 519, 86 P. (2d) at 110. 
bility of the issuer, as the creator of the defective security, should not be extended to bona fide vendors, especially since it is believed that a subpurchaser has the right to recover against the issuer.

Accordingly, there is reasonable doubt whether, even since 1931, a vendor (not an issuer and in nowise affiliated with the issuer and not an underwriter) of a nonnegotiable security issued in violation of the permit provisions of the Act is liable on an implied warranty of validity. But even though it were held that the innocent vendor of such a security impliedly warrants the validity of the instrument, in view of the modern doctrine announced in Eberhard v. Pacific Southwest $L . \&$ \& $M$. Corp.$^{96}$ and other kindred cases, it would seem utterly illogical and inconsistent to charge the vendor who resells a security issued in violation of the permit provisions of the Act with a breach of warranty of validity. Under the doctrine of that case, a security issued in contravention of the permit provisions of the Act is invalid only if the purchaser elects to declare it so. Either the original purchaser or any subsequent purchaser, even though he may have knowledge that the Act has been violated, may at his option exercise all the rights of a holder of valid securities. Consequently, on a resale of a security issued in violation of the Act the vendor does not transfer a security which is invalid for all purposes. Even though the act of resale of itself by such vendor (in the absence of knowledge of the violation) may not amount to a ratification or full affirmance of the transaction between himself and the issuer, nevertheless it would seem clear that, as between such vendor and his subpurchaser, no warranty of validity has been breached. The innocent subpurchaser may enforce the security and exercise all the rights of the holder of valid securities. Since under these decisions the securities are not absolutely void but merely voidable at the behest of the holder, there would appear to be no breach of warranty of validity as between a vendor and his purchaser. In this respect, securities issued in violation of the permit provisions of the Act are not strictly comparable to overissued stock since in the latter case even a bona fide vendor cannot validate the overissued stock.

In summary, the California rule as to liability of a bona fide vendor not affiliated with the issuer would appear to be as follows:

There was no implied warranty of validity either as to negotiable or nomiegotiable instruments prior to 1931 , and there has been no

96 Supra note 32. 
such warranty as to negotiable instruments or stock certificates since 1931. Even as to nonnegotiable instruments there is reasonable doubt as to any implied warranty of validity since 1931, except in the case of the issuer, and even if it be held that there has been such an implied warranty since that time, there would appear to be no breach thereof on a resale by a bona fide vendor to a subpurchaser.

\section{WHO MAY ENFORCE LIABILITY}

\section{Initial Purchaser.}

Generally speaking, any initial purchaser who is not equally culpable with the issuer may recover either from the issuer of securities issued in violation of the Act or from its officers and agents participating in such issue or from all of such persons. However, for the reasons heretofore discussed, there may be some doubt whether an underwriter, as an initial purchaser, could recover from the issuer. As previously stated, as between the issuer and a nonculpable original purchaser, the liability of the issuer is absolute and, generally, the only defense of the issuer is the bar of the statute of limitations. The purchaser is not in pari delicto and, generally speaking, the defenses of estoppel and ratification are not available. However, under special circumstances an initial purchaser may be estopped to assert illegality as a defense, if the rights of third parties intervene, and in other cases the courts, while permitting a negligent purchaser to assert the illegality defensively, deny him affirmative relief. These questions are more fully hereinafter discussed under the caption "Defenses". The question whether a purchaser who has disposed of the securities may recover is also hereinafter discussed.

\section{Subpurchasers.}

-Rights Against Issuers and Agents.

The great majority of the cases which have arisen under the Act have been between the original parties to an issue transaction. However, there have been several cases where subsequent purchasers have successfully sued either the issuer or its officers and agents participating in the issue, or all of such persons. Thus, in the Boss case $^{07}$ a subsequent purchaser sued the issuer and its agents but not his immediate assignor who was the initial purchaser. In the Eberhard case ${ }^{0 s}$ the successful plaintiffs were assignees and not original purchasers.

97 Boss v. Silent Drama Syndicate, supra note 12.

98 Eberhard v. Pacific Southwest L. \& M. Corp., supra note 32. 
In the case of Domestic \& Foreign Pet. Co. v. Long $^{99}$ it was held that a subsequent purchaser could establish his rights in the security even though sold without a permit and even though purchased from one who was in pari delicto with the issuer.

In the case of Mannion v. Baldwin ${ }^{100}$ a director, with full knowledge that stock had been illegally issued to her, "resold" it to an innocent purchaser. It was held that the corporation and the directors and all others who participated were liable. However, while there was a purported resale in this case, the decision really proceeds on the theory that it was an original issue by the corporation, which received all of the consideration from the sale, and therefore the case does not strictly involve a resale between the initial purchaser and a subpurchaser.

The case of Barrett v. Gore ${ }^{101}$ involved undivided interests in an oil lease issued without a permit. Plaintiff, who had purchased one unit directly from the issuer and another from a prior purchaser, was allowed recovery against the issuer for both units.

It would therefore appear clear that under the Act the liability of the issuer extends to every person who acquires the security, and it is believed that this rule would apply no matter how many successive transfers had been made. Privity of contract is not necessary to support the action. Moreover, it is believed that this liability on the part of the issuer would exist and be available to subpurchasers regardless of whether the subpurchaser retained the certificate in "street form" or had it reregistered in his name. The reregistration or transfer on the books would not of itself create the liability. It is the original creation of the security that gives rise to the liability.

None of the cases has made any critical attempt to define the theory or basis of liability of the issuer to remote purchasers. The Boss case was apparently decided on the analogy of overissued stock and on the theory that the issuer is held to a continuing affirmation or representation of the genuineness of the security and that any purchaser has a right to rely on such affirmance without inquiry as to the validity of the certificate. Since stock issued in violation of the Act is strictly not comparable to overissued stock, it is probable that the liability to remote purchasers cannot be entirely satisfactorily explained under strict common-law principles. Nor would there seem to

09 Supro note 34.

100 (1933) $217 \mathrm{Cal}$ 600, 20 P. (2d) 678.

101 (1928) 88 Cal. App. 372, 263 Pac. 564. 
be any need of so doing. ${ }^{102}$ It would appear to be no great strain if the courts simply rested liability under the Act on the theory that the issuer's statutory duty reaches to all persons acquiring the security. There would seem to be no need of any distorted extension of the law of warranty ${ }^{103}$ or of the law of negligence. In any event, it would appear clear that the courts will undoubtedly hold the issuer of a security, issued in violation of the permit provisions of the Act, liable to subpurchasers. There still remain, however, certain perplexing unsolved problems as to the quantum of recovery a subpurchaser is entitled to, which will be considered under a subsequent caption.

It is to be observed that it is only in cases where the security itself is invalidated by the voiding section of the Act that liability runs to remote purchasers. And the liability attaches only to the issuer (and, of course, its agents and those who participate in the issue). Where

102 Even at common law the courts have found no great dificulty in abolishing the old requirement of privity in many fields, without the aid of any statute. The bestknown example has been developed in establishing liability of manufacturers to persons other than their immediate vendees. See Bohlen, Liability of Manufacturers to Persons Other than their Inmediate Vendees (1929) 45 L. Q. REv. 343 ; Notes (1933) 33 CoL. L. REv. 868; (1933) 18 CORN. L. Q. 445 ; (1927) 40 HARv. L. Rev. 836; (1928) 42 ibid. 414; (1932) 45 ibid. 1415 ; (1932) 7 WASH. L. REv. 351.

Such liability has been rested on various theories in different jurisdictions. Thus, in the leading case of MacPherson v. Buick Motor Co. (1916) 217 N. Y. 382, 111 N. E. 1050 , liability was based on a tort for negligence and foreseeability of harm. While the case recognized that the general rule limits liability for negligence to the original parties to the contract of sale, it greatly broadened the well-known exception to the general rule applying to articles inherently dangerous to life or property. In that case the manufacturer of an automobile was held liable to a subvendee for negligence in failing to discover that one of its wheels was defective. Privity was found not to be essential. As stated by the court, the duty is imposed by law. In a subsequent leading case, Glanzer v. Shepard (1922) 233 N. Y. 236, 135 N. E. 275, commenting on the MacPherson case, the New York court of appeals stated: "We do not need to state the duty in terms of contract or of privity ... the duty is imposed by law."

It is arguable that the issuer who creates a defective security is comparable to a manufacturer and should be held to the same liability to remote purchasers to which the manufacturer of a dangerous article is held. However, it would appear wholly unnecessary even to apply this analogy to hold the issuer of a security issued in violation of the Act liable to subpurchasers. The liability of manufacturers to persons other than their immediate vendees was developed at common law in the total absence of statute. In the case of violation of the permit provisions of the Act, it would appear to be a reasonable construction of the Act to hold that the liability of the issuer runs to remote purchasers and that the requirement of privity has been climinated.

103 An assignee's rights under his assignor's warranty are not assigned to a subassignee by the mere assignment of the right against the obligor to which the warranties relate. The rights under such warranties may be expressly assigned. 1 WIILISTON, SAIES (2d ed. 1924) \$244. 
merely the sale or transaction is illegal but the security itself is valid, ${ }^{104}$ the liability of the seller would clearly extend only to his immediate purchaser. ${ }^{105}$

As heretofore discussed, it is not certain whether an underwriter is liable under the Act, and, if so, whether his liability would run only to his immediate purchaser or also to remote purchasers.

\section{-Rights Against Remote Vendor Unaffiliated With the Issuer.}

Even though a bona fide vendor unaffiliated with the issuer who resells securities issued in violation of the permit provisions of the Act were held to an implied warranty of validity-which is quite doubtful in California for the reasons discussed above-it is clear that the liability would run only in favor of his immediate purchaser and would not run in favor of remote purchasers since the great weight of authority is to the effect that an assignee of a chose in action is not entitled to sue remote assignors on implied warranties, privity of contract being essential. ${ }^{108}$

\section{Buyer Who Has Disposed of the Security.}

\section{-Initial Purchaser.}

One of the most perplexing problems under the Act is the question whether a buyer, to whom a security has been sold in violation of the permit provisions of the Act, where there is a total absence of actual fraud and causation of loss, who without knowledge of the violation has resold the security to a third person, is nevertheless entitled to affirmative relief against the issuer. No California case has been found which decides or even discusses this point but, for the reasons hereinafter stated, it is believed that such a buyer is not entitled to any affirmative relief either by way of an action for damages or rescission.

There would appear to be no problem in the case of a buyer who resells the security with knowledge of the statutory violation. If such buyer sells the security after discovery he must be deemed either to have transferred his right of recovery to his assignee or to have abandoned and waived such right. "By selling the shares ... [he] elected

104 Cf. Duntley v. Kagarise, supra note 11.

$105 \mathrm{It}$ is interesting to note that liability under section 11 of the Securities Act of 1933 extends to remote purchasers, but the liability of the seller under section 12 of that act is available only to the immediate buyer.

106 (1939) 27 Cartr. L. Rev. 477; (1931) 44 Harv. L. Rev. 643; Wrenshall State Bank v. Shutt (1930) 202 Wis. 281, 232 N. W. 530; Restateneant, Contracts § 175(4). 
to deal with them as his own." ${ }^{10 \pi}$ Even in case of actual fraud a sale after discovery defeats the right of rescission..$^{108}$

Moreover, the situation is quite different if actual fraud exists in addition to a simple violation of the statute. In such cases the initial buyer who has parted with the security clearly has an action for damages for fraud against the issuer wholly independent of the right of action for the statutory violation.

The real difficulties arise only with respect to the buyer who resells before discovery in the case where there is no actual fraud or causation. The following discussion is accordingly confined to such cases.

At common law a buyer who had resold the goods could nevertheless sue for damages for breach of a warranty of value or quality. ${ }^{109}$

Also, under the majority rule at common law in cases of actual fraud, the defrauded buyer could recover despite the fact that he had resold the goods. ${ }^{110}$

At common law a warranty is not available to a subpurchaser and the mere resale of a warranted article did not give the purchaser a right to sue. However, a right of action already accrued could be assigned separately. ${ }^{111}$

Also at common law, if a defrauded buyer of goods (including securities) resold them, the subpurchaser could not sue the original fraudulent seller. The action for fraud is not upon the contract but is collateral to the contract. ${ }^{112}$

Both warranty and fraud required privity, and in each case the action was personal and, although assignable separately in most jurisdictions, did not pass on a mere resale of the securities.

Thus, at common law neither the seller who breached a warranty of quality nor even the seller guilty of actual fraud was exposed to illimitable and indeterminate risk. He was liable only to one person -his immediate vendee-and not to an endless chain of possible subvendees.

However, the California courts clearly appear to be committed to the principle that the power to validate securities issued in viola-

${ }^{107}$ Levin v. Hornblower (1937) 298 Mass. 340, 341, 10 N. E. (2d) 504, 505.

108 Maginess v. Western Securities Corp. (1918) 38 Cal. App. 56, 175 Pac. 277.

1092 Winuston, Sales (2d ed. 1924) §613; Brown v. Bigelow (1865) 92 Mass.

(10 Allen) 242.

1102 WInLIston, loc. cit. supra note $109 ; 27$ C. J. 99.

1111 WrIIIsTon, op. cit. supra note $109, \S 244$.

112 Hines v. Brode (1914) 168 Cal. 507, 143 Pac. 729. 
tion of the permit provisions of the Act passes to the subpurchaser. No privity is required and the issuer's absolute liability runs to the subpurchaser. Thus, the subpurchaser may recover damages, ${ }^{113}$ or he may assert against the issuer all the rights of the holder of a valid security. ${ }^{114}$

Since under the rule of the Eberhard and kindred cases ${ }^{115}$ it is clear that the subpurchaser is vested with full rights as against the issuer, the real question would appear to be: does the buyer who has sold the security divest himself of all rights? Fraud being totally absent in the hypothetical case under discussion, there is no collateral right of action for fraud. Moreover, the strict rules of warranty and privity do not apply since the requirement of privity has been eliminated. Also, it would appear clear, as hereinabove discussed, that the bona fide vendor of such securities would not be liable to his subpurchaser, thereby removing one of the grounds on which some of the cases at common law predicate the right of a buyer who has resold securities which he purchased in reliance on fraudulent representations, to recover from his fraudulent seller.

Because it is established that the liability of an issuer is assignable by the buyer, ${ }^{116}$ that the right to recover passes to the subpurchaser, ${ }^{117}$ and that the subpurchaser can enforce all the rights of a holder of valid securities, ${ }^{118}$ it would appear that all the rights of the initial purchaser pass to the subpurchaser, and that upon a mere transfer of the security by the initial purchaser no residual rights are left in him. In the Boss, Eberhard and Long cases there was merely a transfer of a security involved. There was no separate assignment of any "collateral right of action."

Under the rule of these cases it would appear that the statutory right of action for violation of the Act is integrated in the security itself. There is no collateral right of action for fraud. Moreover, the right of action is not an action to enforce a statutory penalty. Furthermore, the so-called "warranty" of the issuer passes to the subpurchaser. In view of these considerations, it is difficult to see wherein there is any collateral right detached from the security itself or where-

118 Boss v. Silent Drama Syndicate, supro note 12.

114 Domestic \& Foreign Pet. Co. v. Long, supra note 34.

115 Supra notes 32 to 35.

116 Auslen v. Thompson, supra note 69.

117 Boss v. Silent Drama Syndicate, supra note 12.

118 Domestic \& Foreign Pet. Co. v. Long, supra note 34; Eberhard v. Pacific Southwest L. M. Corp., supra note 32 . 
in the initial buyer who resells would still retain any personal right of action after parting with the security.

It has been stated by several commentators that rescission was the purchaser's sole remedy under the state Blue-Sky laws. ${ }^{110}$ While this undoubtedly is, or at least formerly was, the rnajority rule elsewhere, in California the buyer of securities issued in violation of the Act is not limited to the remedy of rescission.

But, in any event, it would appear clear for the reasons hereinabove stated, that in California the buyer who has disposed of the security should not be entitled to maintain an action for damages. Actual fraud, or special circumstances showing that loss proximately resulted from the innocent breach of statutory duty, should be necessary to sustain such an action.

The commentators on the Securities Act of 1933 practically without exception state that sections 11 and 12 of the act, to the extent that they permit a buyer who has disposed of the security to sue for damages, mark a radical departure from the common law. ${ }^{120}$ The civil liabilities imposed by the Securities Act are not only compensatory in nature but also in terrorem. ${ }^{121}$ Its provision permitting a buyer who has disposed of the securities to sue for damages constitutes a striking innovation to the common law. The remedy was deliberately and expressly provided in a statute which concededly marks a revolutionary change of public policy. However, the courts, in the absence of express legislation, should not impose in terrorem penalties or extend the harsh consequences of actual fraud to fields of innocent conduct where absolute liability is imposed.

But the question remains whether an initial buyer who has sold the securities is nevertheless entitled to relief by way of rescission if he. purchases like securities and tenders them. At equity, at least in some jurisdictions, actual fraud is not required to be proved in an action for rescission. A buyer can often have relief by reason of misrepresentation based upon mistake, or innocent misrepresentation. ${ }^{122}$

110 Note (1934) 48 HaRv. L. Rev. 107, 114.

120 See, e.g., Shulman, loc. cit. supra note 43; Note (1933) 33 Cor. L. REv. 1220, 1234 ("The Act is novel in its extension of the issuer's absolute liability to include . . . immediate purchasers who have disposed of their securities."); Note (1934) 48 Harv. L. REv. 107, 111 ("Section 12 of the Securities Act ... differs from the common law in allowing damages when the security has been sold.")

121 Shulman, op. cit. supra note 43, at 251; Douglas and Bates, The Federal Securities Act of 1933 (1933) 43 YALE L. J. 171, 173.

1222 CoOK, CoRPorations (7th ed. 1913) §356. 
The seller's ignorance of the misrepresentation, whether excusable or not, is no defense. But in such cases the seller's liability does not run to subpurchasers as it does in California for violations of the permit provisions of the Act. Moreover, such relief in equity is granted only if the plaintiff acts promptly and can fully restore the seller to status quo.

In some of the states following the majority rule that rescission is the purchaser's sole remedy for violation of a Blue-Sky law, a purchaser who has resold the securities before he discovers the violation, is entitled to the return of his money on a tender of equivalent shares. ${ }^{123}$ However, it would appear doubtful that in such states the issuer's absolute liability extends to subpurchasers, as it does in California.

In view of the California decisions, it is difficult to comprehend how there could be a full restoration of the status quo where a third party, the subpurchaser, by reason of his ownership of the security, has the power to assert rights against the issuer to the latter's injury.

In the case of negotiable securities it would appear that there could be no rescission after sale to a bona fide subpurchaser for value. Thus, a transfer of a stock certificate cannot be rescinded after it has passed from the transferee to a succeeding bona fide purchaser for value by a legal transfer. ${ }^{124}$ For somewhat similar reasons a promissory note given for an illegal subscription in violation of the Act is nevertheless valid in the hands of a bona fide holder. ${ }^{125}$ Moreover, since it would appear that the buyer passes all his rights by the transfer of the security to a subpurchaser, the same rule should apply to nonnegotiable instruments. Merely tendering like securities by the initial purchaser falls far short of a full restoration which would necessarily enibrace a discharge or surrender of all claims of the subpurchaser. Therefore, in the absence of actual fraud and of special circumstances showing that the actual damages were occasioned by the innocent breach of statutory duty, it is submitted that the buyer who has disposed of the securities issued in violation of the Act, even though he sells without knowledge of the violation, should not be permitted to rescind by purchasing and tendering equivalent securities. Since it would appear that the initial purchaser is not liable to his subpurchaser whereas the issuer is clearly liable to the latter, it would

123 Cf. Vogler v. Gustin (1932) 257 Mich. 475, 241 N. W. 147.

124 6A Cax. Jur. 522; CaL. Civ. CODE § 330.7(1).

125 Pitman v. Walker (1922) 187 Cal. 667, 203 Pac. 739. 
be unduly severe to impose multiple and indeterminate liability, by judge-made law, on the issuer where there is no causal connection between an innocent breach of statutory duty and the actual loss. It would appear extremely harsh to extend the absolute liability of the issuer to remote subvendees and at the same time hold him to a loss sustained by the initial purchaser which had no relation whatsoever to the issuer's innocent violation.

Even under the Securities Act of 1933 with its in terrorem penalties, "trading losses", as distinguished from losses due to material misleading or inadequate statements as of the time of offering the security, offer no ground for action. ${ }^{120}$ Moreover, it would certainly appear clear that under the California Act, which is remedial in nature and contains no express in terrorem penalties, trading losses should not be recoverable by a buyer who has parted with the security. At the utmost, such buyer should be permitted to rescind only in case the loss is directly attributable to the statutory violation, and rescission should be denied in cases where the loss is in noway associated with the violation but merely arose from general economic conditions. It should be stressed that the issuer's liability is absolute despite his innocence and good faith. His liability is even more severe in certain respects than the liability of the issuer under section 11 of the Securities Act of 1933, since under the latter act the issuer has a defense if the purchaser knew of the untruth or omission at the time of acquiring the security, or if the issuer can disprove causation, defenses that are not available under the California Act as construed by the decisions.

The basic rule under the Act would appear to be that the issuer's liability for a statutory violation is limited to the amount it actually receives from the sale. To hold that liability under the Act runs to the subpurchaser regardless of causation, and at the same time exists in favor of a previous owner who has disposed of the security even though his loss is a trading loss resulting from intervening general economic conditions and in noway occasioned by the violation, seems unduly severe. It should be the province of the legislature and not of the courts to extend the reach of absolute liability for innocent conduct to such an extreme length.

-Subpurchaser.

$A$ fortiori, it would appear clear that a remote purchaser who has

126 Baldwin B. Bane, F. T. C. Release, New York Times, Sept. 23, 1933. 
disposed of the securities would not be entitled to any affirmative relief. By reason of the express provisions of section 11 of the Securities Act of 1933, if a single security is traded in many times, each purchaser who sustains a loss is entitled to recovery, even though he has disposed of the security, provided only his loss does not exceed in amount the initial public offering price. For that reason damages are said to be illimitable under section 11 of that act. ${ }^{127}$ But such a novel and extreme degree of "chain" liability would clearly require express statutory provisions. The Corporate Securities Act is wholly silent on such a matter and it would appear that only by the most fantastic distortion of interpretation of the Act could any such illimitable damages be imposed on an issuer.

\section{REMEDIES}

\section{Distinction Between Offensive and Defensive Relief.}

Strikingly different rules apply in cases where violations of the permit provisions of the Act are asserted for affirmative relief from those which apply when the illegality is merely used defensively. In other words, it makes a great deal of difference whether a violation is used as a sword or as a shield. Thus, a defense is never barred by limitations. ${ }^{128}$ Moreover, while, generally speaking, scienter, reliance and causation are theoretically not required to establish liability, they have not been wholly banished, and such elements are of nore importance where affirmative relief is sought than where the illegality is urged defensively. Thus, while a buyer with full knowledge of the violation, who made installment payments on an illegal subscription after discovery and was otherwise negligent, may nevertheless assert the violation as a defense where it is sought to hold him to a stockholder's liability, he will be denied affirmative relief for the payments he made on the ground that they were voluntary payments. " ... With full knowledge of the fraud practiced, he made ratification thereof by repeated renewals of the obligation and later voluntarily discharged it in full. The law withholds its aid from one of the latter class who is so unmindful of his rights." 129

Furthermore, if the violation is merely asserted as a defense there is no need to return anything. ${ }^{130}$ This is true even though the buyer

127 Douglas and Bates, op. cit. supra note 121, at 176; Shulman, op. cit. supra note 43 , at 251 .

123 6A CaL. JUR. 503.

129 First National Bank v. Thompson, supra note 50, at 407, 298 Pac. at 816.

130 6A CAL. JUR. 523. 
not only had full knowledge of the violation but actually participated in the violation and was equally culpable. Such was the situation in the case of Duntley v. Kagarise. ${ }^{131}$ In that case two of the original promoters sold their shares to a third original promoter in violation of escrow conditions of the permit. The buyer was clearly equally culpable with the sellers, but in an action by the sellers to recover on a promissory note given by the buyer relief was denied although the defendant acquired, through the violation, valid and valuable stock for which he paid nothing. The Duntley case is essentially an application of the old pari delicto rule and the law refused its aid to either of the parties in an illegal transaction. It is believed that the defendant would have fared entirely differently had he been attempting to use the Act affirmatively. If the defendant in that case had actually paid the consideration and was seeking affirmative relief, it is clear that his active participation in the transaction would have prevented his recovery under the well-established rule that if a buyer of securities seeking affirmative relief is equally culpable with the seller he will be denied recovery. ${ }^{132}$

While the courts, in innumerable actions seeking to assert stockholders' liability against defendants who have purchased securities issued in violation of the Act, have permitted such buyers to assert the illegality as a defense against creditors, ${ }^{133}$ even in situations where the buyer had full knowledge of the violation, ${ }^{134}$ there is nevertheless a certain amount of inconsistency in the decisions. Other cases reject the defense if the rights of third parties intervene. ${ }^{135}$ While ordinarily notes given for an illegal subscription are invalid, even in the hands of a receiver, ${ }^{136}$ such notes are valid in the hands of a due course holder. ${ }^{137}$ However, the cases are far from uniform on the question whether the statutory violation can be asserted defensively where the rights of third parties intervene, a subject that will be considered further under the caption dealing with the pari delicto rule.

131 Supra note 11.

132 Campbell v. Julian Merger Mines (1931) 11 Cal. App. 649, 295 Pac. 1040.

133 See, e.g., Live Oak Cemetery Ass'n v. Adamson, supra note 11; Kahle v. Stephens, supra note 17; Regan v. Albin, supra note 18.

13* First National Bank v. Thompson, supra note 50.

135 Moore v. Moffatt (1922) 188 Cal. 1, 204 Pac. 220; of. California Western Holding Co. v. Merrill (1935) 7 Cal. App. (2d) 131, 46 P. (2d) 175.

136 Herkner v. Rubin (1932) 126 Cal. App. 677, 14 P. (2d) 1043.

13r Pitman v. Walker, stupra note 125. 
Affrmative Remedies.

-General.

Despite the fact that in California separate courts of law and equity do not exist, that there is but one form of action, and that all appropriate relief is supposedly available in one court, the cases have in many instances falsely emphasized the form of remedy sought. There is a great deal of inconsistency and confusion in the cases under the Act because of slavery to the old traditions of procedure. A single illustration will suffice to demonstrate this. If directors who personally receive some of the consideration paid for stock illegally issued are sued in an action for money had and received, each is severally liable only for the portion of the consideration he actually received. ${ }^{138}$ However, if a director who receives nothing is sued in an action for damages, he is liable for the full amount the buyer paid..$^{138}$

It is true that the Act is silent as to the remedies for civil liability and the measure of damages. The courts have necessarily had to draw on common-law analogies. Nevertheless, there are many illogicalities in the cases. A great deal of the confusion arises out of false emphasis on old forms of action, and out of two earlier substantive doctrines which have since been rejected by the supreme court, the first of which was to the effect that implied fraud was presumed under all circumstances, and the second of which held that every security issued in violation of the Act was absolutely void for all purposes and could not be validated by a bona fide purchaser even to his own advantage. It is only recently that leading cases in the supreme court have clarified a great deal of this confusion and have more accurately defined the true nature of civil liability for violation of the Act. As a consequence, it is now possible to reexamine the entire problem of remedies more accurately, tested by the basic nature of the cause of action rather than the forms of action that have heretofore been chosen.

It has been stated that until recently rescission has been the purchaser's sole remedy under the various Blue-Sky laws. ${ }^{140}$ However, it is clear that the action is strictly not rescission and many California cases hold that the purchaser is not restricted to the remedy by way of rescission. ${ }^{141}$ Also, other commentators have pointed out that in

138 Pollak v. Staunton, supra note 50.

139 Randall v. California L. B. Syndicate, supra note 49 ; Holmquist v. Kent (1933)

219 Cal. 231, 25 P. (2d) 977; Auslen v. Thompson, supra note 69.

140 Note (1934) 48 Harv. L. Rev. 107, 114.

141 See, e.g., Castle v. Acme Ice Cream Co., supra note 5; Randall v. California L. B. Syndicate, supra note 49; Auslen v. Thompson, supra note 69. 
many states the purchaser may pursue various remedies other than rescission for violation of the various Blue-Sky laws. ${ }^{142}$

The old remedy of rescission requires privity. It can be invoked only against the purchaser's immediate seller. For this reason individual director-defendants in various cases have contended that the plaintiff was limited to the sole remedy of rescission and therefore could not recover against them since they were not parties to the sale, or for the reason that they received no part of the consideration paid. But in all such cases it has been held that rescission is not the exclusive remedy. ${ }^{143}$ All individuals participating in the issue of the security are equally liable-privity is irrelevant and it is also immaterial whether such individuals derive any personal gain.

Even though the seller acts in good faith and exercises due care, since the Act is designed to protect buyers and the buyer is not in pari delicto, conduct on his part which would clearly defeat recovery under the strict theory of rescission will ordinarily not bar his right of affirmative relief under the Act unless he is equally culpable with the seller. Thus, conduct which would be deemed to be a ratification and inconsistent with rescission, such as retention of dividends, attendance at directors' or stockholders' meetings, etc., will not bar the remedy, nor will laches, unless coupled with other culpable or negligent conduct. ${ }^{144}$

Furthermore, full restoration of the status quo is not essential, if it would be impracticable or impossible. ${ }^{145}$

On the other hand, despite many statements made in the cases to the effect that tender or return of the security is not necessary, it would appear that all cases involving affirmative relief are substantially based on the theory that restoration or its equivalent is required. It is generally said that the object of rescission is to declare all bets off and merely to reverse the bargain. In general, the cases under the Act reach this result. The civil liabilities under the Act are merely compensatory-they are not in terrorem. Thus, it is said that "the remedy is measured by the actual loss", and the action is not to enforce a penalty. ${ }^{146}$ Even though the plaintiff sues the issuer alone, or directors and other individuals alone, or all of them together, the

142 Note (1937) 23 Iowa L. Rev. 102.

143 See, e.g., Randall v. California L. B. Syndicate, supra note 49; Auslen v. Thompson, supra note 69.

144 Cf. First National Bank v. Thompson, supra note 50.

145 Castle v. Acme Ice Cream Ca., supra note 5.

146 Auslen v. Thompson, supra note 69. 
liability of the group as a whole is limited to what the plaintiff parted with (plus interest), less the value of what he has received. In short, the bargain is merely called off and the plaintiff is made whole. In all the cases where it is stated that there is no necessity of tender or return of the security, it is obvious that the security itself is worthless. In such cases it is clear from the record that the plaintiff received nothing and therefore has nothing to return and tender would be an empty gesture. However, no case has been found where the plaintiff was awarded affirmative relief where he was at the same time permitted to retain the securities if they had any presumptive value. Nor has any case been found where plaintiff was awarded full affirmative relief without offsetting the value of what he had received if what he did receive had value. In this connection, it is interesting to note that the original opinion in the Pickford case contained a paragraph referring to the case of Duntley $v$. Kagarise, ${ }^{14 i}$ reading as follows:

\begin{abstract}
"Similarly, a purchaser of securities sold without a permit therefor may rescind and assert the invalidity of the transaction without tendering back or restoring to the other party what he has received of value, as required by Section 1691 of the Civil Code (Duntley $v$. Kagarise, supra; Imperial Live Stock Co. v. Tracy, 208 Cal. 205). In the Duntley case stock was sold to the defendant in violation of the terms of a permit. He gave a promissory note in part payment of the purchase price. The permit at the time required the stock to be held in escrow 'pending the further order of said commissioner; ... and that while ... so held, the holder of the shares ... shall not sell or offer for sale or otherwise transfer or agree to sell ... such shares until the written consent of said commissioner shall have been obtained so to do.' The seller later validated the shares by obtaining the required consent to the transfer. He then brought suit on the purchaser's note and it was held that he could not recover, although the defendant owned valid and valuable stock which he had not paid for."
\end{abstract}

The first part of the quoted language shows a clear misconception of the true nature of the action in the Duntley case since no affirmative relief was sought in that case by the purchaser. Undoubtedly the supreme court upon a reexamination of its opinion discovered this error and for that reason, when filing its modified opinion on January 5, 1939, denying a petition for rehearing in the Pickford case, struck out the above-mentioned language.

Many of the early cases, aside from the fact that they involved securities which were obviously worthless, were clearly decided on

147 Supra note 11. 
the theory that securities issued in violation of the Act are absolutely void and nonexistent for all purposes and incapable of validation even by a bona fide purchaser-a theory definitely rejected by the doctrine now well established by the Eberhard and kindred cases. Moreover, many of such earlier cases actually involved fraud, or were decided on the theory that in the case of a violation of the Act, implied fraud is conclusively presumed under all circumstances, a doctrine also since rejected by the supreme court in the Pickford case. Consequently, many of the statements made in the earlier cases as to available remedies are of no further validity or at least must be carefully scrutinized and confined to the actual facts involved.

Thus, it is clear that the sweeping rule announced in the Boss case, ${ }^{148}$ to the effect that a purchaser may sue the issuer and all those who participate in the illegal issue for damages on the theory of deceit, is not law in California. Before any such action may be maintained, actual or implied fraud would have to be alleged and proved since, as announced by the Pickford case, the action for violation does not sound in fraud in all circumstances.

\section{- Specific Affirmative Remedies.}

Under the California cases, subject to the special circumstances hereinafter mentioned, the holder of securities issued in violation of the permit provisions of the Act who does not elect to treat the securities as valid, may pursue any one of the three following remedies: ${ }^{140}$

Rescission. He may rescind and recover the consideration paid. ${ }^{150}$ This is true whether the sale is executory or executed. The general rule, of course, is that one rescinding a contract must tender back what he has received thereunder. However, the rule requiring the restoration of whatever may have been received by the party sceking to rescind it does not apply to property which is absolutely and entirely without value. ${ }^{151}$ In many of the California cases, even though

148 Boss v. Silent Drama Syndicate, supra note 12; see also, MacDonald v. Reich \& Lievre, Inc., supra note 50.

149 The case of Woods v. Deck (C. C.A. 9 th, 1940) 112 F. (2d) 739 , decided suhsequent to the decision in the Pickford case, somewhat loosely summarizes the choice of remedies as follows: "The right to recover money paid for securities issued in violation of the Act may be enforced by the purchaser: (1) In an action for money had and received, or (2) By an action to recover for fraudulent misrepresentation as to the validity of the securities, or in an action for breach of an implied warranty of validity, as the case may be." Ibid. at 741.

150 Otten v. Riesener Chocolate Co., supra note 11.

1513 BLACK, Rescission and Canceituation (2d ed. 1929) $\$ 622$. 
not framed on the strict theory of rescission, ${ }^{152}$ tender was made and in some of such cases ${ }^{153}$ it was held that a purchaser may recover the purchase price upon tendering the stock. Of course, if a security is absolutely valueless in fact, no tender is required, since the law does not require a futile act. However, if the security is of any real value there must be restoration. ${ }^{154}$ Thus, if it appears that plaintiff still retains securities which have a presumptive value, he will be limited to the remedy of rescission and not permitted to recover damages without returning the securities. ${ }^{155}$ Even though the seller acts in good faith the buyer seeking rescission will not be barred by laches, nor will conduct, which under old equity rules would be deemed inconsistent with the remedy of rescission, such as retention of dividends, voting of stock, etc., bar relief. Moreover, the courts will undoubtedly apply extremely liberal rules as to the sufficiency of any notice of rescission. . $^{156}$

Common Count. The purchaser may bring an action for money had and received and recover the purchase price paid for such securities. ${ }^{157}$ The cases which hold that an action on the common count is an appropriate remedy proceed on the theory that the certificate is void, worthless and nonexistent. "The common count will always lie for money paid to one in consideration of his agreement to deliver ... something which he is . . . unable to deliver ...."158 Under this theory, since plaintiff has paid out money for which he has received nothing, the law creates an implied promise to restore money which the defendant in equity and good conscience should not retain. The law implies the promise from the receipt of the money to prevent unjust enrichment. The measure of the liability is the amount received. In practically every case on the common count there is an actual finding that the security is worthless or it is obvious from the record that it is of no value. Clearly, under such circumstances tender of the security is not required.

Action for Damages. The purchaser may bring an action for damages for breach of contract or for failure of consideration to recover

152 See, e.g., Boss v. Silent Drama Syndicate, supra note 12.

153 Otten v. Riesener Chocolate Co., supra note 11.

164 Cf. Fairchild v. Western Securities Corp. (1917) 176 Cal. 742, 169 Pac. 363.

155 Brewis v. Toffelmier (1929) 97 Cal. App. 329, 275 Pac. 819.

156 Otten v. Riesener Chocolate Co., supra note 11.

$15 \tau$ Pollak v. Staunton, supra note 50; McClory v. Dodge (1931) 117 Cal. App. 148,

4 P. (2d) 223; Barrett v. Gore, supra note 101.

158 Grove v. Charles W. Barrett Co. (1927) 87 Cal. App. 165, 167, 261 Pac. 739, 740. 
the amount in which he was damaged. He is not limited to the action for rescission. ${ }^{159}$ The action to recover damages for sale of stock without a permit is not one for rescission. ${ }^{100}$ It is believed that, in every case holding that the purchaser may sue in an action for damages without making restoration, either the security was in fact utterly worthless or it was impracticable to make full restoration. In the Castle case, the plaintiff had conveyed to the defendant a going business for which plaintiff received as consideration: (a) the shares of stock in question, (b) an amount in cash, and (c) the assumption of liabilities. He tendered the stock and sued for damages for the alleged value of the stock without tendering the cash he had received or offering to relieve the defendant from the assumption of liabilities. It was held that the buyer is not restricted to the remedy by way of rescission and that the plaintiff could recover damages for the amount suffered without making full restoration. In that case it would have been impracticable to make full restoration and the holding is in full consonance with the principles of equity rescission, since even in rescission suits at equity where it was impossible to make full restoration, money damages could be awarded. However, even the Castle case merely resulted in reversing the bargain and making the plaintiff whole. In several of the other cases individual defendants sought to defend on the grounds that they had not received any part of the purchase price paid for the security and urged that plaintiff could only have rescission against the party actually receiving the consideration, i.e., the issuer. But it is clear, as heretofore pointed out, that all persons participating in the illegal issue are equally liable, regardless of privity or personal gain. Nevertheless, in such cases there is always a finding that the security is worthless or it is obvious from the record that it is of no value. Accordingly, there is nothing to restore even to the group as a whole, and moreover plaintiff is entitled to recover from the group as a whole only when he parted with.

While there is a great deal of confusion in the cases, it would seem of no great consequence what form of action or theory of recovery the buyer pursues. Some of the cases sound in tort, some in quasicontract, others are based on breach of statutory duty, while the Pickford case holds that the liability is grounded on breach of im-

159 Castle v. Acme Ice Cream Co., supra note 5 ; Randall v. California L. B. Syndicate, supra note 49; Holmquist v. Kent, supra note 139; Auslen v. Thompson, supra note 69.

160 Belden v. California Fireproof Storage Co. (1934) 140 Cal. App. 706, 35 P. (2d) 1034. 
plied warranty. The courts apparently have attempted to apply old common-law concepts of procedure too rigidly. But, basically, it should make little difference as far as ultimate result is concerned what form of remedy the plaintiff chooses. The same relief is demanded but only in a different way. ${ }^{161}$

It is the right sought to be enforced and not a form of procedure that is the test. Since it is believed, for the reasons heretofore set forth at length, that the basic liability is created by statute, and is not truly explainable by concepts either of warranty, or negligence or deceit, it would appear that the only essential allegations that would generally be required to be pleaded to state a good cause of action against the issuer for violation are:

(1) That plaintiff purchased for a specified consideration from defendant, securities of its own issue, and still retains them;

(2) That defendant breached its statutory duty by failing to obtain a permit authorizing such sale [or violated the terms of the permit];

(3) That said securities are worthless [or are tendered to defendant]; and

(4) That plaintiff has suffered a specified amount of damage [viz., the consideration paid, with interest thereon, less the amount of any income received].

Since the liability of the issuer is substantially absolute in nature, it is not necessary, generally, to allege or prove scienter, reliance or causation. Nor, if the purchaser elects not to validate the security and it is in fact worthless, is it necessary to allege tender since there is obviously nothing to restore. However, it appears equally clear that in every case seeking affirmative relief, if the security in fact still has value, the purchaser should be required to make restoration or its equivalent. He cannot recover the full purchase price paid and at the same time retain securities having value, since civil liability under the Act is only compensatory and the plaintiff is only entitled to be made whole.

Initial Purchaser.

MEASURE OF DAMAGES

While California was clearly wedded to the so-called warranty measure of damages ${ }^{162}$ in the case of deceit prior to the adoption of

161 Cf. Hemmeon v. Amalgamated C. Mines Co. (1928) 95 Cal. App. 400, 403, 273 Pac. 74, 75.

162 Two conflicting measures of damages were developed under the common law with respect to fraudulent sales, and the jurisdictions have heen classified accordingly: 
Civil Code section 3343 in 1935, none of the California cases arising under the Corporate Securities Act has ever even suggested this measure of damages, despite the fact that many of the cases involved actual fraud or were grounded on the theory of conclusively implied fraud. No California case has been found which applies any measure of damages other than restitution or indemnity for the actual pecuniary loss suffered. Of course, under the rule of the Eberhard and kindred cases, the innocent buyer may affirm and in such a case is entitled to all the rights of the holder of a valid security. However, if he elects to sue, it would appear clear under all the cases that he is entitled only to compensatory damages. Thus, in the Boss case, plaintiff was permitted to recover what he had actually paid, plus interest. In cases where the buyer has given property he is permitted to recover the actual property or its fair value. ${ }^{163}$

In McClory v. Dodge ${ }^{164}$ it is stated:

"The rule is also well settled in this state that one who has been induced by fraud to part with property, receiving nothing in return, will be entitled to recover the full value of what he has thus given."

The remedy is measured by the actual loss. The action is not an action to enforce a penalty. ${ }^{165}$

Regardless of whether the action has been stated by the courts to sound in fraud, quasi-contract, warranty, or breach of statutory duty, the plaintiff has been permitted to recover only what he actually parted with less the value of what he received. Thus, in Becker $v$. Stineman $n^{166}$ plaintiff was held entitled to recover the property which

(1) the so-called "tort" measure, which is the difference between the purchase price and the market value at the time of delivery; and (2) the so-called "warranty" measure, which is the difference between the value as represented and the actual (or market) value at the time of delivery. Notes (1928) 57 A. L. R. 1142; (1937) 108 A. L. R. 1060. The one, it is said, merely makes the plaintiff whole by limiting damages to what he parted with less the value of what he has received; the other gives him the benefit of his bargain, and recognizes as a legitimate element of damages the prospective profits the vendee expected to make by the transaction. In fraud cases, California, until new Civil Code section 3343 was added in 1935, followed the so-called "warranty" measure prevailing in a majority of jurisdictions. The rule was established in the leading case of Hines v. Brode, supra note 112, which apparently fixed value as of the time of sale and not as of the time of discovery of the fraud.

163 Castle v. Acme Ice Cream Co., supra note 5; Randall v. California L. B. Syndicate, supra note 49.

164 Supra note 157, at 152, 4 P. (2d) at 225.

165 Auslen v. Thompson, supra note 69.

168 (1931) 115 Cal. App. 740, 2 P. (2d) 444. 
he had given for the securities, or its value, less the dividends plaintiff had received. Of course, interest is also allowed from the date plaintiff advances the consideration. ${ }^{167}$

In limiting relief to compensatory damages, the Corporate Securities Act (as construed by the cases) differs widely from the Securities Act of 1933. Because liability under section 11 of the latter act runs to remote purchasers, and since a single security may be traded in many times, there is in theory no limit to liability under that section. However, it would appear axiomatic that no in terrorem liabilities similar to those of section 11 of the Securities Act of 1933 should be imposed except by express legislation.

As heretofore indicated, the California cases are clear and apparently unanimous to the effect that the initial purchaser is only entitled to compensatory damages. His recovery is limited to what he parted with less the value of what he received.

\section{Subpurchaser.}

However, the cases are not clear as to the measure of damages recoverable by a subpurchaser. It is believed that a subpurchaser should not be entitled to recover any greater amount than the issuer (including its agents and other persons participating in the issue) received on the original issue of the security. Trading losses occasioned by wholly independent intervening causes, such as general economic conditions having no causal connection whatever with the original issue and violation of the Act, should not be recoverable. To allow such trading losses would appear to work a severe hardship on the issuer. At least, it would seem clear that the imposition of such unlimited liability would have to be expressly imposed by the legislature and could not be created by judicial interpretation. Thus, it is believed that if $X$ Company sold a security in violation of the permit provisions of the Act to $A$ for $\$ 100$, and $A$ subsequently resold such security to $B$ for $\$ 200, B$, if he elected not to validate the security and sued the issuer, $X$ Company, should be entitled to recover only $\$ 100$, i.e., the amount received by the issuer, and of course if the security still had any actual value $B$ would have to return the security for the reasons hereinabove discussed. There are of course many unsolved minor problems which might arise. It would appear that the subpurchaser would be entitled to interest from the date he acquired

16r Mary Pickford Co. v. Bayly Bros., Inc., supra note 52; Boss v. Silent Drama Syndicate, supra note 12. 
the security, but there would have to be deducted any income received by him thereon.

As previously noted, there have been several California cases in which subpurchasers were permitted to recover. However, in none of these cases was there any thorough or satisfactory discussion of the problem of damages permitted a subpurchaser. In the Boss case $^{10 s}$ the subpurchaser paid $\$ 500$ for five units which were expressed on the face of the certificate to have a par value of $\$ 100$ each. While there were some allegations in the pleadings that Boss' assignor, Keady, the original purchaser from the issuer, had paid less than par for the securities, there was no finding on the point and no discussion of the matter by the appellate court. By the judgment, Boss was entitled to recover the full amount paid by him, i.e., $\$ 500$, plus interest from the date of his payment. However, even though the issuer did not receive the full $\$ 500$ in that case, the decision is justifiable on the ground that the issuer, by fixing a par value of $\$ 100$ per unit which was expressed on the face of the certificate without any indication that they had been issued at less than par, would be held to a representation that such securities were fully paid up.

The case of Barreit v. Gore ${ }^{169}$ involved one unit of the par value of $\$ 3,000$ purchased directly from the issuer at a price of $\$ 2,850$ and another similar unit purchased from a prior purchaser who had paid $\$ 2,000$ therefor, but the record is silent as to the anount paid by plaintiff to the prior purchaser. However, the complaint sought recovery from the defendants, as a group, of the total sum of $\$ 4,850$, which was the exact amount they, as a group, had received from plaintiff and plaintiff's assignor. The appeal was taken from a judgment of nonsuit and the reversal by the higher court of the nonsuit was apparently based on the theory that plaintiff was entitled to a recovery of the full amount actually received by the defendants as a group. The court stated: "Money paid by a purchaser of units or shares in any company, under such void sale, may be recovered in an action in assumpsit, as for money had and received."150

In any event, in the absence of express legislation on the matter it would seem unjustifiable to hold an issuer for trading losses wholly unconnected with the act of original issuance. Even under section 11 of the Securities Act of 1933 the issuer's liability is limited with re-

168 Boss v. Silent Drama Syndicate, ibid.

109 Stupra note 101.

170 Ibid. at 378,263 Pac. at 566. 
spect to any one buyer to the price at which the securities were offered to the public, i.e., substantially the amount originally received by the issuer, and it would seem an undue hardship to impose any greater liability under the California Act. Certainly, it would seem clear that the imposition of any such greater liability would call for express action by the legislature. 